High salt drives Th17 responses in experimental autoimmune encephalomyelitis without impacting myeloid dendritic cells Peer-reviewed author version

Jörg, Stefanie; Kissel, Jan; Manzel, Arndt; KLEINEWIETFELD, Markus; Haghikia, Aiden; Gold, Ralf; Müller, Dominik N. \& Linker, Ralf A. (2016) High salt drives Th17 responses in experimental autoimmune encephalomyelitis without impacting myeloid dendritic cells. In: EXPERIMENTAL NEUROLOGY, 279, p. 212-222.

DOI: 10.1016/j.expneurol.2016.03.010

Handle: http://hdl.handle.net/1942/21526 


\title{
High salt drives Th17 responses in experimental autoimmune encephalomyelitis without impacting myeloid dendritic cells
}

\author{
Stefanie Jörg ${ }^{1}$, Jan Kissel ${ }^{1}$, Arndt Manzel ${ }^{1}$, Markus \\ Kleinewietfeld ${ }^{2,3}$, Aiden Haghikia ${ }^{4}$, Ralf Gold ${ }^{4}$, Dominik N . \\ Müller ${ }^{5}$, Ralf A. Linker ${ }^{1 *}$
}

${ }^{1}$ Department of Neurology, Friedrich-Alexander-University Erlangen-Nuremberg, Germany

${ }^{2}$ Translational Immunology, Medical Faculty Carl Gustav Carus, Dresden, Germany

${ }^{3}$ VIB Laboratory of Translational Immunomodulation, Hasselt University, Diepenbeek,

Belgium

${ }^{4}$ Department of Neurology, Ruhr-University Bochum, Germany

${ }^{5}$ Experimental and Clinical Research Center \& Max-Delbrück Center Berlin, Germany

* Corresponding author: Prof. Dr. Ralf Linker, MD, Schwabachanlage 6, D-91054 Erlangen, Germany, Ralf Linker, tel: +49-9131-85-32187, e-mail: ralf.linker@uk-erlangen.de 


\begin{abstract}
Recently, we have shown that high dietary salt intake aggravates $\mathrm{T}$ helper cell (Th) 17 responses and neuroinflammation. Here, we employed in vitro assays for myeloid dendritic cell (mDC) maturation, DC cytokine production, $\mathrm{T}$ cell activation and ex vivo analyses in murine experimental autoimmune encephalomyelitis (EAE) to investigate whether the salt effect on Th17 cells is further mediated through DCs in vivo. In cell culture, an excess of $40 \mathrm{mM}$ sodium chloride did neither affect the generation, maturation nor the function of DCs, but, in different assays, significantly increased Th17 differentiation. During the initiation phase of $\mathrm{MOG}_{35-55} \mathrm{EAE}$, we did not observe altered DC frequencies or co-stimulatory capacities in lymphoid organs, while IL-17A production and Th17 cells in the spleen were significantly increased. Complementary ex vivo analyses of the spinal cord during the effector phase of EAE showed increased frequencies of Th17 cells, but did not reveal differences in phenotypes of CNS invading DCs. Finally, adaption of transgenic mice harboring a MOG specific $\mathrm{T}$ cell receptor to a high-salt diet led to aggravated clinical disease only after active immunization. Wild-type mice adapted to a high-salt diet in the effector phase of EAE, bypassing the priming phase of $\mathrm{T}$ cells, only displayed mildly aggravated disease. In summary, our data argue for a direct effect of $\mathrm{NaCl}$ on Th17 cells in neuroinflammation rather than an effect primarily exerted via DCs. These data may further fuel our understanding on the dietary impact on different immune cell subsets in autoimmune diseases, such as multiple sclerosis.
\end{abstract}

\title{
Keywords
}

Sodium chloride; myeloid dendritic cells; co-culture; high-dietary salt; experimental autoimmune encephalomyelitis 


\section{Introduction}

High dietary salt intake is a major culprit in cardiovascular disease (Mozaffarian et al., 2014), cancer (D'Elia et al., 2014), chronic inflammation (Sundstrom et al., 2014) and also autoimmune disease (Farez et al., 2014; Hucke et al., 2015). In particular, the significant rise in the incidence of autoimmune diseases like multiple sclerosis (MS) suggests an important contribution of changing environmental factors rather than genetics. Here, most impressively, dietary habits like the so called 'Western diet', high in both fat and sodium, may play a role. On a high-salt diet, both humans and rodents do not exhibit elevated plasma sodium levels, but display sodium accumulation within the skin and muscle in a regulatory mechanism independent from the kidney (Kopp et al., 2012; Machnik et al., 2009; Rakova et al., 2013; Wiig et al., 2013). Interestingly, lymphoid tissues also display a higher sodium osmolality (Go et al., 2004). The influence of increased osmolality in certain compartments within the body on the activation, function and recruitment of immune cells has been the focus of recent research (Ip et al. 2015; Safa et al., 2015; Zhang et al., 2015). By mimicking these in vivo shifts, the addition of an excess of $40 \mathrm{mM}$ sodium chloride $(\mathrm{NaCl})$ to $\mathrm{T}$ cell cultures promoted the differentiation of pathogenic T helper (Th) 17 cells (Kleinewietfeld et al., 2013; Wu et al., 2013). Further studies identified the serum- and glucocorticoid-regulated kinase-1 (SGK1) as a key mediator of this salt-augmented activation of Th17 cells (Kleinewietfeld et al., 2013; Wu et al., 2013). Additionally, a high-salt diet aggravated murine experimental autoimmune encephalomyelitis (EAE; Kleinewietfeld et al., 2013; Wu et al., 2013), a Th1/Th17 model disease mimicking many features of MS (Gold et al., 2006). This finding was confirmed in two genetically divergent strains of mice in a sex-dependent fashion: exposure to high dietary sodium exacerbated EAE and correlated with enhanced breakdown of the blood-brain barrier (BBB) as well as more severe brain pathology (Krementsov et al., 2015). A subsequent epidemiologic study in MS patients demonstrated that an increased dietary sodium intake was associated with a higher risk of MS relapse and inflammatory activity as shown by magnetic 
resonance imaging (Farez et al., 2014). More recent work focusing on the effects of $\mathrm{NaCl}$ on phagocytes showed that high salt enhanced chemotaxis in macrophages (Muller et al., 2013) and increased the expression of pro-inflammatory mediators via p38 or Erk1/2 and cFosmediated pathways (Zhang et al., 2015). Further studies provided evidence that an increase in salt may also perturb regulatory immune cells like regulatory T cells (Treg) and IL-4+IL-13 alternatively activated (so called "M2") macrophages, thus deflecting the immune homeostasis (Binger et al., 2015; Hernandez et al., 2015; Safa et al., 2015).

Dendritic cells (DCs) are professional antigen presenting cells (APCs) with the capacity to ingest and process antigens in peripheral tissue and then migrate to draining lymph nodes where they are able to interact with $\mathrm{T}$ cells. DCs undergo a maturation process accompanied by cytokine production, up-regulation of major histocompatibility complex II (MHCII) and costimulatory molecules, as well as enhanced ability of $\mathrm{T}$ cell activation (Steinman et al., 1991; Schuler 2011). The ability of various environmental factors to modulate the interaction between APCs and T cells is well documented (Diepold, 2008), although the precise mechanisms of such modulations are not well understood.

Hence, in our current study, we investigate the effects of $\mathrm{NaCl}$-induced hypertonicity on the activation and function of myeloid DCs (mDCs) and provide evidence that in autoimmune neuroinflammation, high salt effects on $\mathrm{T}$ cells are rather directly exerted than primarily mediated via DCs. 


\section{Methods}

Primary splenocyte culture. Splenocytes from naïve wild-type mice were stimulated in vitro with $2 \mu \mathrm{g} / \mathrm{ml} \alpha \mathrm{CD} 3 / \alpha \mathrm{CD} 28$ for $48 \mathrm{~h}$ in the presence of urea, mannitol or glycerol (each $80 \mathrm{mM}$ ) or different concentrations of $\mathrm{NaCl}(5,10,40,80 \mathrm{mM})$. Cytokines secreted into the supernatant were assayed by ELISA. $\alpha \mathrm{CD} 3: 145-2 \mathrm{C} 11 ; \alpha \mathrm{CD} 28: 37.51$.

Generation of BMDCs. Bone marrow cells were isolated from femur and tibia by flushing with R10 medium containing 10\% (v/v) Fetal calf serum (FCS; Gibco), 1\% (v/v) L-Glutamine (Pan Biotech) and 1\% (v/v) Penicillin-Streptomycin (Pan Biotech). The cell suspension was sedimented and re-suspended in $0.14 \mathrm{M}$ ammonium chloride solution for 10 minutes to lyse erythrocytes. Mixed bone marrow cells were then washed, counted and maintained in 6 well culture plates at a density of $1 \times 10^{6}$ cells $/ \mathrm{ml}$ in $\mathrm{R} 10$ medium containing recombinant mouse GM-CSF (5 ng/ml) and recombinant mouse IL-4 (5 ng/ml). Cells were cultured for 10 days with or without 20,40 or $80 \mathrm{mM} \mathrm{NaCl}$. Medium was changed on days 3 and 6, and cells were matured on day 8 with $1 \mu \mathrm{g} / \mathrm{ml}$ LPS (Sigma-Aldrich) and 20 $\mu \mathrm{g} / \mathrm{ml} \mathrm{MOG}_{35-55}$.

Isolation of naïve $\mathbf{T}$ cells. Splenic $\mathrm{T}$ cells were isolated by magnetic activated cell sorting (MACS) using the "pan T cell isolation kit II" according to the manufacturer's instructions (Miltenyi Biotech). Isolated T cells were collected and re-suspended in MACS buffer at $3 \times 10^{7}$ cells $/ \mathrm{ml}$. For APC free differentiation, cells were fluorescently stained for $30 \mathrm{~min}$ in an antibody cocktail containing aCD4-FITC (RM4-5, eBioscience), aCD44-PE (IM7, BioLegend), $\alpha$ CD62L-APC (MEL-14, eBioscience) and $\alpha$ CD25-PE-Cy5 (PC61.5, eBioscience) and were subsequently isolated by fluorescence activated cell sorting on MoFlo (Beckman-Coulter) in the FACS-core unit in Erlangen, Germany. Naïve T cells were used for co-culture assays with DCs.

Co-culture assay. For the co-culture assay, mature $\mathrm{MOG}_{35-55}$ laden DCs were seeded with naïve transgenic $\mathrm{T}$ cells harboring a MOG specific TCR at a ratio of 1:6 with or without 40mM NaCl. For Th17 differentiation, IL-6 (40 ng/ml) and TGF $\beta 1(1 \mathrm{ng} / \mathrm{ml})$ were added to 
the culture. Th17 frequencies were analyzed 96h later by intracellular staining via flow cytometry.

Phagocytosis assay. Fluoresbrite ${ }^{\circledR}$ YG Carboxylate Microspheres $0.75 \mu \mathrm{m}$ (Polysciences) were opsonized in mouse plasma diluted to $50 \%$ with Krebs' Ringer PBS for 30 min at $37{ }^{\circ} \mathrm{C}$ under continuous mixing. Microparticles were diluted in R10 Medium to a final concentration of $3 \times 10^{\wedge} 6$ particles $/ \mathrm{ml}$. $2 \mathrm{ml}$ of opsonized particles were added to $1 \times 10^{\wedge} 6$ plated BMDCs and incubated for $0 \mathrm{~h}, 6 \mathrm{~h}$ and $20 \mathrm{~h}$ under humidified conditions $\left(5 \% \mathrm{CO} 2,37^{\circ} \mathrm{C}\right)$. Cells were transferred into FACS tubes and stained for phagocytosed particles in CD11c ${ }^{+}$cells.

Migration assays were performed with $5 \times 10^{\wedge} 5$ BMDCs with standard Transwell@ Permeable Supports with a polycarbonate membrane of $5 \mu \mathrm{m}$ pore size. Lower compartments contained ReMed with $10 \%$ FCS. $500 \mu \mathrm{L}$ cell suspension in ReMed $0.5 \%$ FCS were added into the upper insert compartment. Migration properties were analyzed $20 \mathrm{~h}$ later by flow cytometry after staining the floating, adhering und transmigrating CD $11 \mathrm{c}^{+}$fractions.

Animal experimentation. C57BL/6J mice were initially purchased from Charles River (Sulzfeld, Germany), mice harboring a transgenic MOG specific T cell receptor (2D2 mice; Bettelli et al., 2003) were a kind gift from Prof. V. Kuchroo, Boston, USA. All mice were housed at the Franz-Penzoldt-Zentrum (FPZ), the animal care facility of the University Erlangen-Nuremberg (Germany) under a 12 hour day-night-cycle and standardized environmental conditions receiving normal chow (SNIFF E15431-34EF R/M; 0.4\% NaCl) and tap water ad libitum. All mice strains bred in-house were backcrossed on C57BL/6 background for at least 10 generations. All experiments were in accordance with the German laws for animal protection and were approved by the local ethic committees (Erlangen AZ 542532.1-56/12).

High-salt diet. For experiments under high-salt diet, mice received chow containing $4 \% \mathrm{w} / \mathrm{w}$ sodium chloride ( $\mathrm{NaCl}$; based on SNIFF E15431-34EF R/M) and tap water containing 1\% w/w $\mathrm{NaCl}$ in three different settings: 
(1) Wild-type mice were adapted to high-salt chow for 2 weeks prior to induction of active $\mathrm{MOG}_{35-55}$ EAE (Figure 3-5).

(2) MOG transgenic 2D2 mice (Bettelli et al., 2003) were adapted to high-salt chow for 25 days and scored by visual inspection for tearing, gluing and reddening of eyes as symptoms for optic neuritis as well as for EAE symptoms such as ataxia and paresis before actively inducing $\mathrm{MOG}_{35-55}$ EAE after 50 days of exposure to high-salt diet (Figure 6A).

(3) For modeling the impact of $\mathrm{NaCl}$ during the effector phase of EAE, wild-type mice were actively immunized with $\mathrm{MOG}_{35-55}$ and then randomly adapted to high-salt or control diet at the onset of symptoms (Figure 6B).

EAE induction. For EAE induction, 8-11 week-old mice were anaesthetized and subcutaneously injected with $200 \mu \mathrm{g} \mathrm{MOG}_{35-55}$ and $200 \mu \mathrm{g}$ CFA. Pertussis toxin (200 ng/mouse) was applied intraperitoneally on days 0 and 2 p.i. Clinical symptoms were assessed daily according to a 10-point scale ranging from 0 (no symptoms) to 10 (moribund; Linker et al., 2002). For disease courses, only mice with clinical symptoms were included.

Isolation of splenic cells. Spleens of mice on high-salt or control diet were removed on day 10 p.i. and disrupted with a $5 \mathrm{ml}$ glass homogenizer. The tissue was then filtered through a $100 \mu \mathrm{m}$ cell-strainer followed by an erythrocyte lysis. After washing with cold DPBS, cells were processed by intracellular cytokine staining and ex vivo flow cytometry analysis.

Isolation of CNS infiltrating cells. Spinal cord was removed on day 14 p.i. and disrupted with a $5 \mathrm{ml}$ glass homogenizer. Tissue was strained through a $100 \mu \mathrm{m}$ cell-strainer followed by a three step density gradient $(30 \%, 45 \%$ and $70 \%$ isotonic PercollTM). The density gradient was centrifuged for $20 \mathrm{~min}$ at $800 \mathrm{~g}$ without brake. After centrifugation, cells were harvested from the interphases, washed with cold PBS and resuspended in Re-medium for intracellular cytokine staining and ex vivo flow cytometry analysis. 
In vitro MOG restimulation assay. Splenocytes from EAE mice were obtained on day 10 p.i. and seeded at a density of $3 \times 10^{6}$ cells $/ \mathrm{ml}$ in Re-medium. $\mathrm{MOG}_{35-55}(20 \mu \mathrm{g} / \mathrm{ml})$ and Concanavalin A $(1.25 \mu \mathrm{g} / \mathrm{ml})$ were added for stimulation, and supernatants were harvested 48h later and analyzed for cytokines.

Cytokine detection. Cytokine concentrations in cell culture supernatants were analyzed by enzyme-linked immunosorbent assay (ELISA) for the secretion of IL-17a, IFN- $\gamma$, IL-10, IL1beta, IL-6, IL-12 p35 and IL-23 p19 (all R\&D) according to the manufacturer's instructions. Flow cytometry. Ex vivo obtained splenic cells, CNS infiltrating cells and in vitro differentiated Th cells were analyzed by staining for extra- and intracellular markers. In vitro generated BMDCs were stained for extracellular markers. Dead cells were excluded by a fixable viability dye eFluor ${ }^{\circledR} 780(0.2 \mu 1 /$ test $)$. Nonspecific Fc-mediated interactions were blocked by addition of $0.5 \mu \mathrm{l} \alpha \mathrm{CD} 16 / 32$ (93, eBioscience) for $10 \mathrm{~min}$. For surface staining, cells were stained with the respective fluorochrome conjugated antibodies for $30 \mathrm{~min}$ in PBS. For intracellular cytokine staining, cells were stimulated with ionomycin $(1 \mu \mathrm{M})$ and PMA $(50 \mathrm{ng} / \mathrm{ml})$ in the presence of monensin $(2 \mu \mathrm{M})$ for 4 hours. Cells were stained for surface marker and made permeable by saponin buffer or Fix/Perm (eBioscience) according to the manufacturer's protocol. Intracellular cytokines were stained with the respective fluorochrome conjugated antibodies for 30-45 min.

Real-time PCR. Gene expression was analyzed by real time PCR in cultured cells or tissue. Cells were lysed in RLT-buffer (RNeasy kit, QIAGEN), and total RNA was isolated using the RNeasy kit following the manufacturer's instructions (QIAGEN). Animal tissue was homogenized in $500 \mu \mathrm{L}$ RLT buffer with an Ultra-Turrax for 30s followed by total RNA isolation with RNeasy Minicolumns (RNeasy kit, QIAGEN). RNA yield was quantified by absorbance measurements at $260 \mathrm{~nm}$. $1000 \mathrm{ng}$ of total RNA were used per reaction to reversely transcribe RNA into cDNA, using QuantiTect ${ }^{\circledR}$ transcriptases according to the protocols (QIAGEN). PCR reactions were performed at a $5 \mu \mathrm{l}$ scale on a qTower real time 
PCR System (Analytic Jena) in triplicates. Relative quantification was performed by the $\Delta \Delta \mathrm{CT}$ method, normalizing target gene expression on Actb/ $\beta$-Actin as housekeeping gene.

Statistical analysis. Statistical analysis was performed using GraphPad Prism (GraphPad Software Inc., La Jolla, CA). All in vitro and ex vivo data were analyzed by one-way ANOVA followed by Tukey`s post-test, unpaired t-test or Wilcoxon rank sum test after checking for normal distribution (unless indicated otherwise in the legends). EAE data were analyzed by Mann-Whitney U test. Data are presented as mean $\pm \mathrm{SEM} ;{ }^{*} \mathrm{p}<.05,{ }^{*} \mathrm{p} p .01$, or $* * * \mathrm{p}<$ .001 were considered to be statistically significant. 


\section{Results}

\section{$\mathrm{NaCl}$ primes IL-17A production in splenocyte culture.}

A first set of experiments analyzed effects of increased $\mathrm{NaCl}$ concentrations on immune cells in vitro. To this end, different osmolytes were added to mixed splenocyte culture after $\alpha \mathrm{CD} / \alpha \mathrm{CD} 28$ stimulation. We found that adding urea and glycerol slightly decreased IL-17A secretion whereas mannitol had no effect. Flow cytometry analysis revealed no increased cell death in response to the osmolytes as compared to the control culture. However, increasing salt concentrations up to $80 \mathrm{mM} \mathrm{NaCl}$ increased cell death (data not shown). The addition of an excess of $40 \mathrm{mM} \mathrm{NaCl}$ specifically resulted in a dose-dependent, two-fold increase of interleukin-17A (IL-17A) which was not seen after addition of other osmolytes at the same osmolality (Figure 1A). The $\mathrm{NaCl}$ effect was specific for IL-17A, as the expression of interferon- $\gamma$ (IFN- $\gamma$ ) (Figure 1B) and IL-10 (Figure 1C) did not change in response to increased $\mathrm{NaCl}$ concentrations. To investigate whether this salt effect on IL-17A production was directly exerted on Th17 cells or indirectly mediated via DCs, we next investigated effects of an excess of $\mathrm{NaCl}$ on mDCs in vitro.

\section{NaCl has no significant influence on murine DC generation, maturation and function.}

To determine whether high concentrations of $\mathrm{NaCl}$ alter $\mathrm{DC}$ generation or maturation, bone marrow derived myeloid DCs (BMDCs) were generated in vitro from bone marrow precursor cells in the presence or absence (control) of an excess of 20,40 or $80 \mathrm{mM} \mathrm{NaCl}$ to cell culture media and analyzed for their surface marker expression by flow cytometry. The generation of BMDCs was not affected by increased $\mathrm{NaCl}$ concentrations (supplementary figure 1). Based on our previous studies (Kleinewietfeld et al., 2013) and the above stated results (Figure 1) we focused our further studies on $40 \mathrm{mM} \mathrm{NaCl}$. The addition of an excess of $40 \mathrm{mM} \mathrm{NaCl}$ was not associated with a reduction in the frequency of BMDCs (Figure 2A). Flow cytometric analysis of either untreated or NaCl-treated BMDCs showed no differences in the surface expression levels of classical activation markers like the antigen-presenting molecule MHCII 
or co-stimulatory molecules cluster of differentiation 86 (CD86) and CD80 (Figure 2B-D). $\mathrm{NaCl}$ did not alter the mean fluorescence intensity (MFI) of above mentioned markers (supplementary figure 1B). When analyzing the BMDC gene expression profile, we found no significant effect in IL-1 $\beta$, IL-6, IL-12a, IL-23r and IL-23a expression in BMDCs generated in the presence of an excess of $40 \mathrm{mM} \mathrm{NaCl}$ as compared to controls (Figure 2E, supplementary figure 1C). The expression of serum- and glucocorticoid-regulated kinase-1 (SGK1) in mDC was not affected by high salt concentrations (Figure 2E). As mature DCs are professional APCs with the capacity to activate $\mathrm{T}$ cells, we next investigated the impact of $\mathrm{NaCl}$ on the $\mathrm{T}$ cell stimulatory capacity of BMDCs. To this end, BMDCs were generated in the presence or absence of an excess of $40 \mathrm{mM} \mathrm{NaCl}$ before mature $\mathrm{MOG}_{35-55}$ laden $\mathrm{BMDCs}$ were co-cultured with naïve $\mathrm{CD} 4^{+} \mathrm{T}$ cells harboring a MOG transgenic $\mathrm{T}$ cell receptor (TCR) with or without additional $40 \mathrm{mM} \mathrm{NaCl}$ for four days. To assess if high-salt directly induced differentiation of pathogenic Th17 cells or acts via DCs, polarizing cytokines were added to the co-culture. As shown in Figure 2F and supplementary figure 2, Th17 frequencies were significantly increased only upon addition of excess $\mathrm{NaCl}$ to the co-culture assays, regardless whether BMDCs were pre-treated with $\mathrm{NaCl}$, arguing for a direct effect of salt on $\mathrm{T}$ cells in fostering Th17 polarization. To further elaborate on DC function, we performed in vitro experiments for antigen uptake and migration with BMDCs generated with or without an excess of $40 \mathrm{mM} \mathrm{NaCl}$. Neither antigen uptake capacity nor migration behavior was affected by excess salt concentrations (Figure 2G, H).

\section{High dietary salt directly acts on T cells rather than on APCs during EAE.}

In a next step, we performed ex vivo analyses of mice that were adapted to a diet rich in $\mathrm{NaCl}$ and compared them to mice on a control diet. Flow cytometric analysis of splenocytes revealed an increase of Th17 and Th1 cells (Figure 3A, B) of mice adapted to a high-salt diet during the initiation phase of EAE (d10 post immunization/p.i.). In contrast, frequencies of mDCs and CD11b positive cells in splenocytes were not affected by the high-salt diet at 
similar time points (Figure 3C). In line with these observations, we did not detect quantitative differences in the total cell numbers of mDCs between mice on a high-salt diet and controls (Figure 3D). Moreover, a high-salt diet did not affect the expression of MHCII as well as the co-stimulatory molecules $\mathrm{CD} 80$ and $\mathrm{CD} 86$ in $\mathrm{CD} 11 \mathrm{c}^{+}$cell populations (Figure 3E-G). Analyzing total cell numbers (Figure 3F) as well as MFI values (Supplementary figure 3) revealed no effects of increased $\mathrm{NaCl}$ concentrations.

In good agreement with the increased frequencies of Th17 and Th1 cells in the spleen of mice on a high-salt diet (Figure 3A), RT-PCR analyses revealed a significant increase in the expression of Ill7a, Ifng, Tbx21 (Tbet) in the spleen on day 10 p.i. (Figure 4A). Yet, further quantitative gene expression analysis did not reveal large effects of a high-salt diet on DCs, as gene expression analysis of Itgax (CD11c), Itgam (CD11b), Cd80, Cd86, Il23a or Il12a did not display significant differences between both groups. Only the expression of $I l 1 b$ (IL-1 $\beta$ ) was slightly upregulated under these conditions in total splenocytes (Figure 4B). As recent research demonstrated that high-salt could boost pro-inflammatory M1 macrophages (Ip et al., 2015; Zhang et al., 2015) but blunts the induction of alternatively activated M2 macrophages (M(IL-4+IL-13)) (Binger et al., 2015), we additionally analyzed typical markers for M1 (Figure 4C) and M2 macrophages (Figure 4D) at early phases of EAE. Yet, an increased salt intake was not associated with altered gene expression of both types of macrophages during the initiation phase of EAE, neither after normalization of gene expression to Actb ( $\beta$-actin) (Figure 4C,D) nor Cd68 (data not shown). Instead, the influence of high-salt intake on Th17 cells was confirmed by a splenocyte recall assay on day 10 of EAE. Cytokine analysis by ELISA revealed an increased IL-17A and also IFN- $\gamma$ secretion on day 10 p.i.. No significant changes in the secretion of IL-1 $\beta$ and IL-6 could be observed (Figure 4E-H). Further, we did not find significant expression of p19 as IL-23 subunit and p35 as IL-12 subunit was only detectable after Concanavalin A (ConA) stimulation, independently of the diet (data not shown). 
To investigate whether dietary salt exerts delayed effects on mDCs in vivo, we analyzed frequencies and total cell numbers of DCs as wells as macrophages and T cells in the spinal cord on day 14 p.i.. On that time point, mice on a high-salt diet revealed a two score point higher disease severity than mice on a control diet (high-salt diet: $6.3 \pm 0.37$ vs control: $4.0 \pm$ $0.53 ; \mathrm{p}=0.0011, \mathrm{n}=6$ per group). In good correlation with our findings during the initiation phase of EAE, salt imprints its effects only on Th cells (Figure 5A,B). More precisely, mice on a high-salt diet showed increased infiltration of Th17 cells but not Th1 cells, whereas mDC frequencies were not affected (Figure 5C). In line with this, total mDC numbers did not differ between high-salt and control diet mice (Figure 5D). Analyzing the activation status of mDCs in the CNS revealed no effect of a high-salt diet (Supplementary figure 4). Gene expression analysis of the spinal cord on day 14 p.i. revealed increased expression of $1117 a$ (Figure 5E), thus confirming the elevated infiltration of Th17 cells in mice adapted to a high-salt diet. Besides this, mice on a high-salt diet displayed an increased expression if Ifng (Figure 5E). The gene expression of mDC markers (Figure 5F) or macrophage markers (Figure 5G, $\mathbf{H}$ ) was not altered in mice that had been adapted on a high-salt diet.

Finally, we modeled the influence of $\mathrm{NaCl}$ during the effector phase of neuroinflammation in two EAE paradigms in vivo, bypassing the priming phase of $\mathrm{T}$ cells. First, mice harboring a transgenic MOG specific TCR (2D2 mice) were adapted to a $\mathrm{NaCl}$ rich diet for 25 days. In this model, salt exposure alone did neither lead to classical EAE symptoms nor symptoms of optic neuritis. Without immunization, clasping behavior was observed in 6/13 mice under high-salt diet and 5/13 mice in the control group (data not shown). Yet, active $\mathrm{MOG}_{35-55}$ immunization of 2D2 mice adapted to a high-salt diet for 50 days led to a more severe course of EAE (Figure 6A). There was no difference in disease incidence between both groups (data not shown). In a second approach, we adapted wild-type C57BL/6 mice to a high-salt diet after the initiation phase of active $\mathrm{MOG}_{35-55} \mathrm{EAE}$ at the onset of first clinical symptoms. Mice 
receiving a high-salt diet still displayed a more severe disease course as compared to controls (Figure 6B). Yet, the disease enhancing effects were much smaller than in mice adapted to a high-salt diet already before immunization (Kleinewietfeld et al., 2013; Wu et al., 2013).

\section{Discussion}

$\mathrm{NaCl}$ aggravates neuroinflammation and Th17 responses (Kleinewietfeld et al., 2013; Wu et al., 2013) and since the interaction of DCs with naïve Th cells is important for the differentiation and activation of Th17 cells (Gutcher et al., 2007), investigating salt induced effects on Th17 cells and neuroinflammation via DCs seemed worthwhile. We here show that $\mathrm{mDC}$ function is not significantly influenced by salt induced hypertonicity in vivo. Our data rather argue for a direct effect of $\mathrm{NaCl}$ on Th17 cells in neuroinflammation, which is well in line with previous observations (Kleinewietfeld et al., 2013; Wu et al., 2013). Of interest, at the time points studied, a high-salt diet also increased IFN- $\gamma$ secretion in vivo, which may be explained by the early phase of EAE where plasticity of Th17 cells is known to occur (Hirota et al., 2011). Moreover, after high salt exposure, $\mathrm{Wu}$ et al. detected an increase of IFN- $\gamma$ expression in IL-17A co-expressing cells in vivo (Wu et al., 2013) and a more recent study also found an increased IFN- $\gamma$ production of Tregs (Hernandez et al., 2015). Thus, it is possible that high-salt conditions may promote IFN- $\gamma$ production of some $\mathrm{T}$ cell subtypes in vivo, depending on the cytokine environment and timing.

So far, $\mathrm{NaCl}$ induced effects on immune cells have been described for Th17 cells (Kleinewietfeld et al., 2013; Wu et al., 2013) regulatory T cells (Hernandez et al., 2015; Safa et al., 2015) and macrophages including M2 polarization (Binger et al., 2015; Ip et al., 2015; Zhang et al., 2015). Our data presented here support the concept that distinct immune cell subtypes respond differently to $\mathrm{NaCl}$ and that the salt induced generation of a proinflammatory environment involves specific effects on immune cells rather than unspecific activation of all lymphocytes and APCs. This notion is also underscored by the different 
signaling pathways induced by high $\mathrm{NaCl}$ in $\mathrm{T}$ cells and $\mathrm{M} 1$ versus $\mathrm{M} 2$ macrophages (Kleinewietfeld et al., 2013; Binger et al., 2015).

The lack of $\mathrm{NaCl}$ effects on DCs may be explained by several factors: First, our study focused on $\mathrm{NaCl}$ effects on $\mathrm{mDC}$. This does not exclude effects on plasmacytoid DCs, which have been shown to play an important role in EAE (Galicia et al., 2014) and also MS (Stasiolek et al., 2006) and which may be particularly important for the priming of Th17 responses in EAE (Isaksson et al., 2009).

Second, our data on $\mathrm{mDC}$ focus on their role during the initiation phase of EAE where priming of Th cell responses mainly occurs. Notably, Th17 cells were shown to play a pivotal role as drivers of myeloid cells in the initial effector phase of EAE (Codarri et al., 2013). This may link $\mathrm{NaCl}$ effects seen in Th17 cells to those seen in macrophages in EAE. While we did not observe quantifiable differences in CD11b positive cell populations under a high-salt diet during the initiation phase of EAE (day 10 p.i.), this does not exclude effects of myeloid cells and especially macrophages in the later course of EAE. The slight increase of IL-1 $\beta$ expression in the spleen on day 10 of EAE might be due to other cells like macrophages, since IL-1 $\beta$ is not an exclusive marker for mDCs. This may be particularly conceivable in neuroinflammation since effects of $\mathrm{NaCl}$ on the pro-inflammatory activation status of macrophages have clearly been shown in different cardiovascular and infectious models (Machnik et al., 2009; Jantsch et al., 2015). Consistent with prevailing direct effects of $\mathrm{NaCl}$ on $\mathrm{T}$ cell differentiation in neuroinflammation, 2D2 mice do not exhibit a higher incidence of spontaneous EAE after high-salt exposure, but a more severe disease course after active immunization as already reported in wild-type mice (Kleinewietfeld et al., 2013; Wu et al., 2013). Along the same line, the exposure to a high-salt diet during the predominantly macrophage-driven effector phase of EAE only displays mild disease enhancing effects, which are much smaller than those under a high-salt diet already before immunization. 
Third, our analyses focus on the effects of a high-salt diet in the spleen and spinal cord. Yet, the exact primary site where a high-salt diet may influence immune cells remains to be determined. While it has been shown that focal osmolality in immune organs significantly differs from plasma, recent data also focus on the gut as a regulatory organ for diet-induced effects on neuroinflammation (Haghikia et al., 2015).

Finally, we did not observe gene expression changes of IL-4+Il-13+ alternatively activated „M2“ macrophages in the spleen on day 10 of EAE, neither after normalizing to $\beta$-actin nor to CD68 as a macrophage marker. Yet, effects of high salt exposure on M2 polarization have clearly been shown in vitro and in vivo (Binger et al., 2015; Zhang et al., 2015). However, the early phase of $\mathrm{MOG}_{35-55} \mathrm{EAE}$ in $\mathrm{C} 57 \mathrm{BL} / 6$ mice is not a classical M2 macrophage-mediated disease model. Again, this cell type may be more relevant at later disease phases or in other organs than the spleen.

In summary, the exposure to a high-salt diet in the early phase of neuroinflammation mainly acts on Th17 cells and is independent of myeloid cells such as mDC. This observation may have important consequences for our understanding of the dietary induced influences on different immune cell subsets in autoimmune diseases such as MS. 


\section{Figure legends}

\section{Figure 1}

$\mathrm{NaCl}$ primes IL-17A production in splenocyte culture.

(A) Quantification of IL-17A expression in mixed splenocyte culture after stimulation with $\alpha \mathrm{CD} / \alpha \mathrm{CD} 28$ antibodies in the presence of different osmolytes or increasing concentrations of $\mathrm{NaCl}(\mathrm{n}=6$, data pooled from two experiments). (B,C) Quantification of IFN- $\gamma(\mathrm{B})$ or IL-10 (C) expression in mixed splenocyte culture after $\alpha \mathrm{CD} / \alpha \mathrm{CD} 28$ stimulation in the presence of excess $40 \mathrm{mM} \mathrm{NaCl}(\mathrm{n}=6$, data pooled from two experiments). All data are shown as mean \pm SEM. $* * p<.01$ or $* * * p<.001$.

\section{Figure 2}

$\mathrm{NaCl}$ does not influence DC generation, maturation and function in vitro.

(A) Flow cytometry analysis of CD11c frequencies of in vitro generated BMDCs $(n=3$

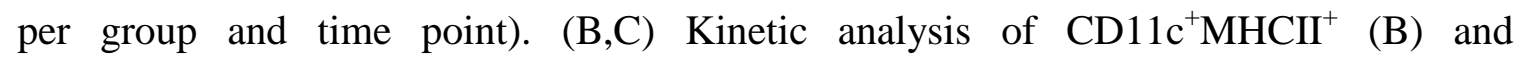
$\mathrm{CD} 11 \mathrm{c}^{+} \mathrm{CD} 80^{+}(\mathrm{C})$ cell frequencies of in vitro generated BMDCs by flow cytometry $(\mathrm{n}=3$ per group and time point). (D) Representative contour plot of a kinetic analysis of

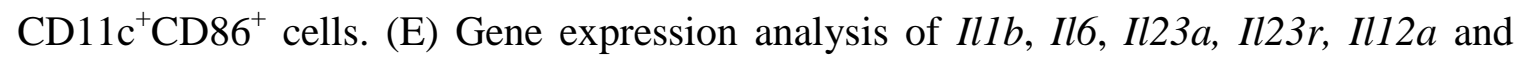
Sgkl of in vitro generated BMDCs on day 10 of culture ( $\mathrm{n}=5$ per group). (F) Addition of $40 \mathrm{mM} \mathrm{NaCl}$ to a co-culture assay of naïve T cells and BMDCs generated in the presence $(\mathrm{BMDCs}+\mathrm{NaCl})$ or absence (BMDCs control) of $40 \mathrm{mM} \mathrm{NaCl}(\mathrm{n}=4$, one out of four independent experiments shown). (G) Kinetic analysis of phagocytosed particles in $\mathrm{CD} 11 \mathrm{c}^{+}$cells by flow cytometry ( $\mathrm{n}=2$ per time point, one out of two experiments shown).

(H) Frequencies of floating, adhering and migrating CD11 ${ }^{+}$cells after $20 \mathrm{~h}$ incubation on $5 \mu \mathrm{m}$ transwell membranes. All data are shown as mean \pm SEM. $* * \mathrm{p}<.01$ or $* * * \mathrm{p}<.001$; ns $=$ not significant 


\section{Figure 3}

High dietary salt directly acts on T cells rather than on APCs in the priming phase of EAE. Wild-type mice were adapted to a high-salt diet two weeks prior to active immunization with $\mathrm{MOG}_{35-55}$ peptide. (A-D) Ex vivo flow cytometry analysis of (A) frequencies and (B) total cell numbers of Th17 and Th1 cells in the spleen on day 10 p.i. ( $\mathrm{n}=5$ mice per group). (C) Analysis of $\mathrm{mDC}$ and CD11b positive cell frequencies and total cell numbers (D) in the spleen on day 10 p.i.. (E,F) Frequencies (E) and total cell

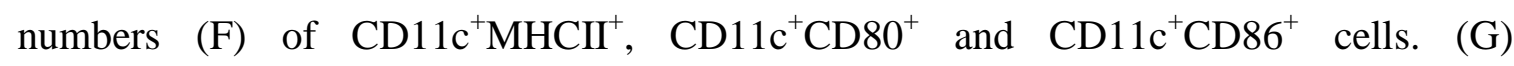

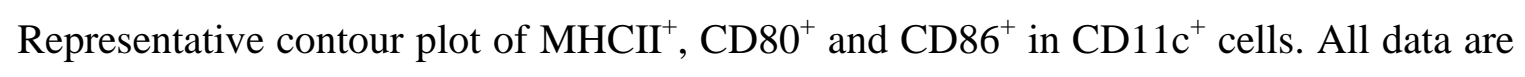
shown as mean \pm SEM. $* \mathrm{p}<.05, \mathrm{~ns}=$ not significant, $\#=$ total cell number.

\section{Figure 4}

High dietary salt affects Th17 cells but not DCs during EAE.

Wild-type mice were adapted to a high-salt diet two weeks prior to active immunization with $\mathrm{MOG}_{35-55}$ peptide. (A-D) Gene expression analysis of characteristic $\mathrm{T}$ cell markers (A), mDC markers (B), M1 macrophage markers (C) and M2 macrophage markers (D) in the spleen on day 10 p.i. ( $\mathrm{n}=5$ mice per group). $\beta$-Actin was used as loading control. Itgax (Integrin alpha X, CD11c), Itgam (Integrin alpha M, CD11b), Nos2 (Nitric oxide synthase 2), Argl (arginine hydrolase, Arginase 1), Mrcl (mannose receptor, CD206), Fizzl (also known as Retnla, or resistin-like $\alpha$ ), Yml (also known as Chi3l3, or Chitinaselike 3), Mgl2 (Macrophage galactose-type C-type lectin 2, CD301b). (E-G) Cytokine measurement of IL-17A (E), IFN- $\gamma(\mathrm{F})$, IL-1 $\beta(\mathrm{G})$ and IL-6 (H) in cultures after ex vivo recall with $\mathrm{MOG}_{35-55}$ (splenocytes harvested on day 10 p.i. of $\mathrm{MOG}_{35-55} \mathrm{EAE}, \mathrm{n}=5$ per group). All data are shown as mean \pm SEM. $* \mathrm{p}<.05, * * \mathrm{p}<.01 ; \mathrm{ns}=$ not significant. 


\section{Figure 5}

High dietary salt increases frequencies of CNS invading Th17 cells but not DCs.

Wild-type mice were adapted to a high-salt diet two weeks prior to active immunization with $\mathrm{MOG}_{35-55}$ peptide. (A-D) Ex vivo flow cytometry analysis of the spinal cord on day 14 p.i. ( $\mathrm{n}=5$ mice per group). (A) Frequencies and (B) total cell numbers of Th17 and Th1 cells invading the spinal cord. (C) Frequencies and (D) total cell numbers of mDCs and $\mathrm{CD} 11 \mathrm{~b}^{+}$cells. (E,F) Gene expression analysis of Ill7 and Ifng (E) and Itgax, Itgam, $C d 86$ and $I l l b(\mathrm{~F})$ in the spinal cord on day 14 of $\mathrm{MOG}_{35-55} \mathrm{EAE}(\mathrm{n}=5$ mice per group). $(\mathrm{G}, \mathrm{H})$ Gene expression analysis of M1 markers $(\mathrm{G})$ and $\mathrm{M} 2$ markers $(\mathrm{H})$ in the spinal cord on day 14 of $\mathrm{MOG}_{35-55}$ EAE ( $\mathrm{n}=5$ mice per group). $\beta$-Actin was used as loading control in all RT-PCR analysis. All data are shown as mean \pm SEM. $*$ p $<.05, * * p<.01$; ns $=$ not significant $\#=$ total cell number.

\section{Figure 6.}

High-salt diet during the effector phase mildly aggravates EAE.

(A) Clinical course of $\mathrm{MOG}_{35-55}$ EAE in MOG TCR transgenic 2D2 mice after active immunization. Mice were adapted to high-salt chow 50 days prior to immunization and displayed a significant, by 3 -score points more severe EAE than the controls $(n=13$ per group, one representative experiment out of two is shown). (B) Clinical course of active $\mathrm{MOG}_{35-55} \mathrm{EAE}$ in wild-type mice. Mice were randomized into two groups and adapted to high-salt or control diet after the onset of first symptoms (from day 11 to 17 , see bar above graph; $n=8$ mice per group, one representative experiment out of two is shown). All data are shown as mean \pm SEM. $* \mathrm{p}<.05$. 


\section{Acknowledgments}

We wish to thank A. Hammer for helpful discussions and advice as well as S. Seubert and K. Bitterer for expert technical assistance. Cell sorting was supported by the FACS Core Unit, Nikolaus-Fiebiger-Center, Friedrich-Alexander-University Erlangen, Germany. RAL holds an endowed professorship supported by the Novartis Foundation. M.K. was supported by the European Research Council (ERC) under the European Union's Horizon 2020 research and innovation programme (640116). 


\section{References}

Bettelli, E., Pagany, M., Weiner, H.L., Linington, C., Sobel, R.A., Kuchroo, V.K. 2003. Myelin oligodendrocyte glycoprotein-specific $\mathrm{T}$ cell receptor transgenic mice develop spontaneous autoimmune optic neuritis. J. Exp. Med. 197:1073-1081.

Binger, KJ., Gebhardt, M., Heinig, M., Rintisch, C., Schroeder, A., Neuhofer, W., Hilgers, K., Manzel, A., Schwartz, C., Kleinewietfeld, M., Linker, R.A., Lang, F., Voehringer, D., Wright, M.D., Hubner, N., Dechend, R., Jantsch, J., Titze, J., Muller, D.N. High salt reduces the activation of IL-4+IL-13 stimulated macrophages, J Clin Invest. 2015 Oct 20. pii: 80919

Codarri, L., Greter, M., Becher, B. 2013. Communication between pathogenic T cells and myeloid cells in neuroinflammatory disease. Trends Immunol. 34(3):114-9.

D'Elia, L., Galletti, F., and Strazzullo, P. 2014. Dietary salt intake and risk of gastric cancer. Cancer Treat Res 159:83-95.

Diepold, S.S. 2008. Determination of T-cell fate by dendritic cells. Immunol Cell Biol 86(5):389-97

Farez, M.F., Fiol, M.P., Gaitan, M.I., Quintana, F.J., and Correale, J. 2014. Sodium intake is associated with increased disease activity in multiple sclerosis. J Neurol Neurosurg Psychiatry.

Galicia, G., Gommerman, J.L. 2014. Plasmacytoid dendritic cells and autoimmune inflammation. Biol Chem. 395(3):335-46.

Go, W.Y., Liu, X., Roti, M.A., Liu, F., and Ho, S.N. 2004. NFAT5/TonEBP mutant mice define osmotic stress as a critical feature of the lymphoid microenvironment. Proc Natl Acad Sci U S A 101:10673-10678.

Gold, R., Linington, C., Lassmann, H. 2006. Understanding pathogenesis and therapy of multiple sclerosis via animal models: 70 years of merits and culprits in experimental autoimmune encephalomyelitis research. Brain 129(Pt 8):1953-71.

Gutcher, I., Becher. B. 2007. APC-derived cytokines and T cell polarization in autoimmune inflammation. J Clin Invest.117(5):1119-27.

Haghikia, A., Jörg, S., Duscha, A., Berg, J., Manzel, A., Waschbisch, A., Hammer, A., Lee, D.H., May, C., Wilck, N., Balogh, A., Ostermann, A., Schebb, N.H., Akkad, D.A., Grohme, D.A., Kleinewietfeld, M., Kempa, S., Thöne, J., Demir, S., Müller, D.N., Gold, R., Linker, R.A. 2015. Dietary fatty acids directly impact central nervous system autoimmunity via the small intestine. Immunity. 43: 817-829.

Hernandez, A.L., Kitz, A., Wu, C., Lowther, D.E., Rodriguez, D.M., Vudattu, N., Deng, S., Herold, K.C., Kuchroo, V.K., Kleinewietfeld, M., Hafler, D.A. 2015. Sodium chloride inhibits the suppressive function of FOXP3+ regulatory T cells. J Clin Invest. doi:10.1172

Hirota, K., Duarte, J.H., Veldhoen, M., Hornsby, E., Li, Y., Cua D.J., Ahlfors, H., Wilhelm, C., Tolaini, M, Menzel, U., Garefalaki, A., Potocnik, A.J., Stockinger, B. 2011. Fate mapping of IL-17-producing T cells in inflammatory responses Nat. Immunol. 12(3): 255-263. 
Hucke, S., Wiendl, H., Klotz, L. 2015. Implications of dietary salt intake for multiple sclerosis pathogenesis. Mult Scler. 1352458515609431

Ip, WK., Medzhitov, R. 2015. Macrophages monitor tissue osmolarity and induce inflammatory response through NLRP3 and NLRC4 inflammasome activation. Nat Commun. 6:6931

Isaksson, M., Ardesjö, B., Rönnblom, L., Kämpe, O., Lassmann, H., Eloranta, ML., Lobell, A. 2009. Plasmacytoid DC promote priming of autoimmune Th17 cells and EAE. Eur J Immunol. 39(10):2925-35.

Jantsch, J., Schatz, V., Friedrich, D., Schröder, A., Kopp, C., Siegert, I., Maronna, A., Wendelborn, D., Linz, P., Binger, K.J., Gebhardt, M., Heinig, M., Neubert, P., Fischer, F., Teufel, S., David, JP., Neufert, C., Cavallaro, A., Rakova, N., Küper, C., Beck, FX., Neuhofer, W., Muller, D.N., Schuler, G., Uder, M., Bogdan, C., Luft, FC, Titze, J. 2015. Cutaneous $\mathrm{Na}+$ storage strengthens the antimicrobial barrier function of the skin and boosts macrophage-driven host defense. Cell Metab 21(3):493-501.

Kleinewietfeld, M., Manzel, A., Titze, J., Kvakan, H., Yosef, N., Linker, R.A., Muller, D.N., and Hafler, D.A. 2013. Sodium chloride drives autoimmune disease by the induction of pathogenic TH17 cells. Nature 496:518-522.

Kopp, C., Linz, P., Dahlmann, A., Hammon, M., Jantsch, J., Müller, D.N., Schmieder, R.E., Cavallaro, A., Eckardt, K.U., Uder, M., Luft, F.C., Titze, J. 2013. 23Na magnetic resonance imaging-determined tissue sodium in healthy subjects and hypertensive patients. Hypertension. 61(3):635-40.

Krementsov, DN., Case, LK., Hickey, WF., Teuscher, C. 2015. Exacerbation of autoimmune neuroinflammation by dietary sodium is genetically controlled and sex specific. FASEB J. 29(8):3446-57. doi: 10.1096/fj.15-272542.

Linker, R.A., Mäurer, M., Gaupp, S., Martini, R., Holtmann, B., Giess, R., Rieckmann, P., Lassmann, H., Toyka, K.V., Sendtner, M., Gold, R. 2002. CNTF is a major protective factor in demyelinating CNS disease: a neurotrophic cytokine as modulator in neuroinflammation. Nat Med. 8(6):620-624.

Machnik, A., Neuhofer, W., Jantsch, J., Dahlmann, A., Tammela, T., Machura, K., Park, J.K., Beck, F.X., Muller, D.N., Derer, W., et al. 2009. Macrophages regulate saltdependent volume and blood pressure by a vascular endothelial growth factor-Cdependent buffering mechanism. Nat Med 15:545-552.

Mozaffarian, D., Fahimi, S., Singh, G.M., Micha, R., Khatibzadeh, S., Engell, R.E., Lim, S., Danaei, G., Ezzati, M., and Powles, J. 2014. Global sodium consumption and death from cardiovascular causes. N Engl J Med 371:624-634.

Muller, S., Quast, T., Schroder, A., Hucke, S., Klotz, L., Jantsch, J., Gerzer, R., Hemmersbach, R., and Kolanus, W. 2013. Salt-dependent chemotaxis of macrophages. PLoS One 8:e73439.

Rakova, N., Jüttner, K., Dahlmann, A., Schröder, A., Linz, P., Kopp, C., Rauh, M., Goller, U., Beck, L., Agureev, A., Vassilieva, G., Lenkova, L., Johannes, B., Wabel, P., Moissl, U., Vienken, J., Gerzer, R., Eckardt, KU., Müller, DN., Kirsch, K., Morukov, B., Luft, 
FC., Titze, J. 2013. Long-term space flight simulation reveals infradian rhythmicity in human $\mathrm{Na}(+)$ balance. Cell Metab. 17(1):125-31

Safa, K., Ohori, S., Borges, TJ., Uehara, M., Batal, I., Shimizu, T., Magee, CN., Belizaire, R., Abdi, R., Wu, C., Chandraker, A., Riella, LV. 2015. Salt Accelerates Allograft Rejection through Serum- and Glucocorticoid-Regulated Kinase-1-Dependent Inhibitionof Regulatory T Cells. J Am Soc Nephrol. 26(10):2341-7.

Schuler, G. 2011. Dendritic cells: indispensable? Cancer J. 17(5):337-42

Stasiolek M., Bayas A, Kruse N, Wieczarkowiecz A, Toyka K.V, Gold R, Selmaj K. 2006. Impaired maturation and altered regulatory function of plasmacytoid dendritic cells in multiple sclerosis. Brain 129(Pt 5):1293-305.

Steinman, R.M., Young, J.W. 1991. Signals arising from antigen-presenting cells. Curr Opin Immunol. 3(3):361-72.

Sundstrom, B., Johansson, I., and Rantapaa-Dahlqvist, S. 2014. Interaction between dietary sodium and smoking increases the risk for rheumatoid arthritis: results from a nested case-control study. Rheumatology (Oxford).

Wiig, H., Schroder, A., Neuhofer, W., Jantsch, J., Kopp, C., Karlsen, T.V., Boschmann, M., Goss, J., Bry, M., Rakova, N., et al. 2013. Immune cells control skin lymphatic electrolyte homeostasis and blood pressure. J Clin Invest 123:2803-2815.

Wu, C., Yosef, N., Thalhamer, T., Zhu, C., Xiao, S., Kishi, Y., Regev, A., and Kuchroo, V. 2013. Induction of pathogenic TH17 cells by inducible salt-sensing kinase SGK1. Nature 496:513-517.

Zhang, WC., Zheng, XJ., Du, LJ., Sun, JY., Shen, ZX., Shi, C., Sun, S., Zhang, Z., Chen, XQ., Qin, M., Liu, X., Tao, J., Jia, L., Fan, HY., Zhou, B., Yu, Y., Ying, H., Hui, L., Liu, X., Yi, X., Liu, X., Zhang, L., Duan, SZ. 2015. High salt primes a specific activation state of macrophages, $\mathrm{M}(\mathrm{Na})$. Cell Res. 25(8):893-910 
A

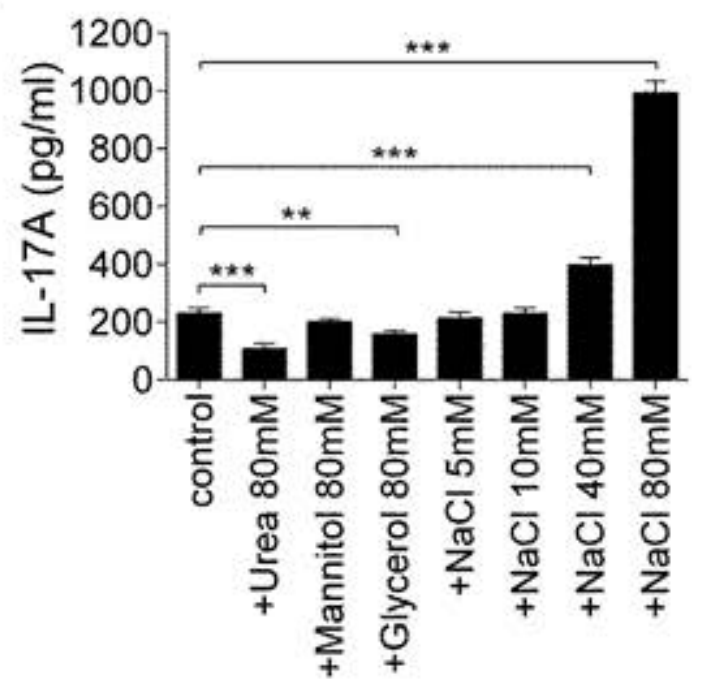

B

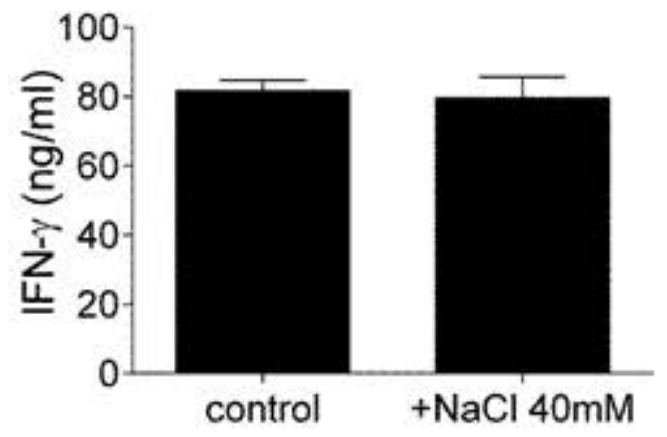

C

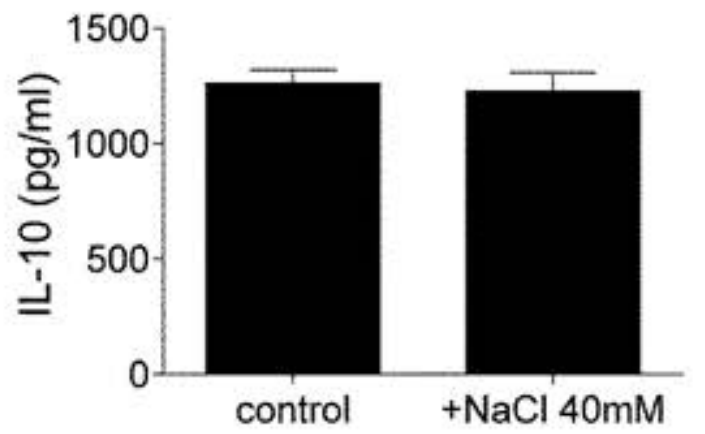

Jörg et al. Figure 1 
A

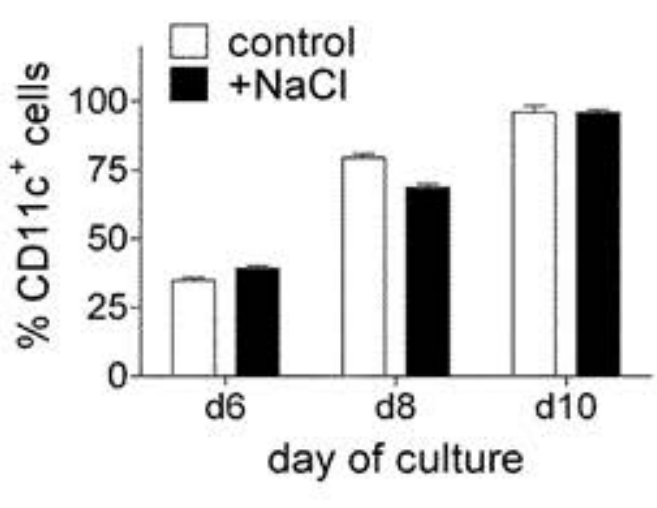

C

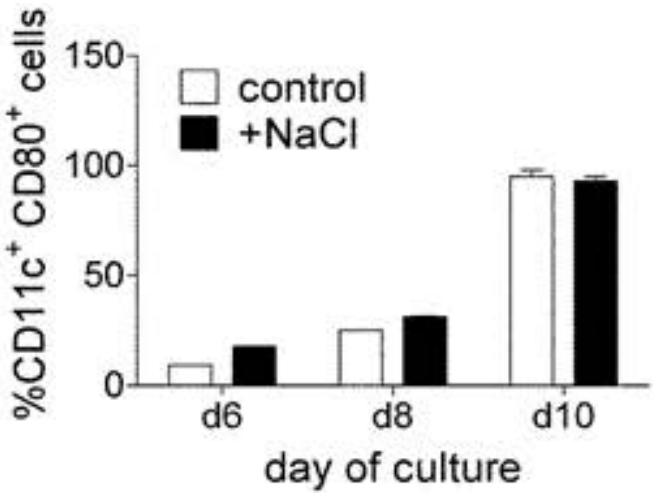

E

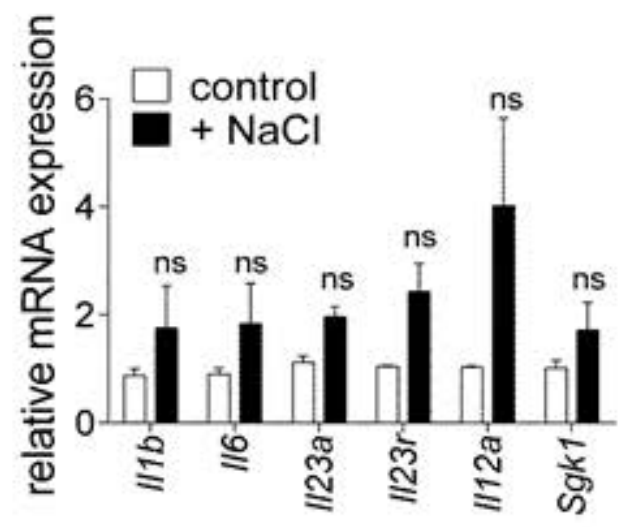

G $\frac{\mathscr{\omega}}{\bar{\delta}}$

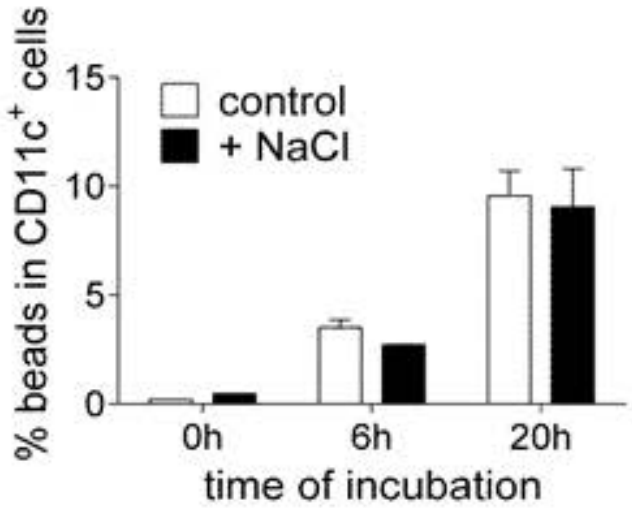

B

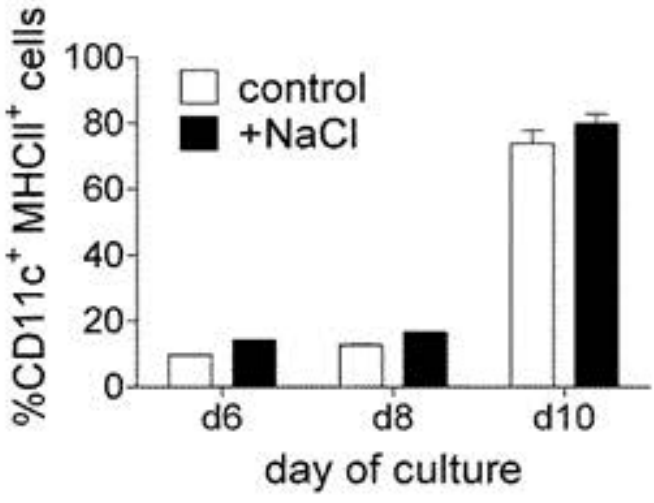

D

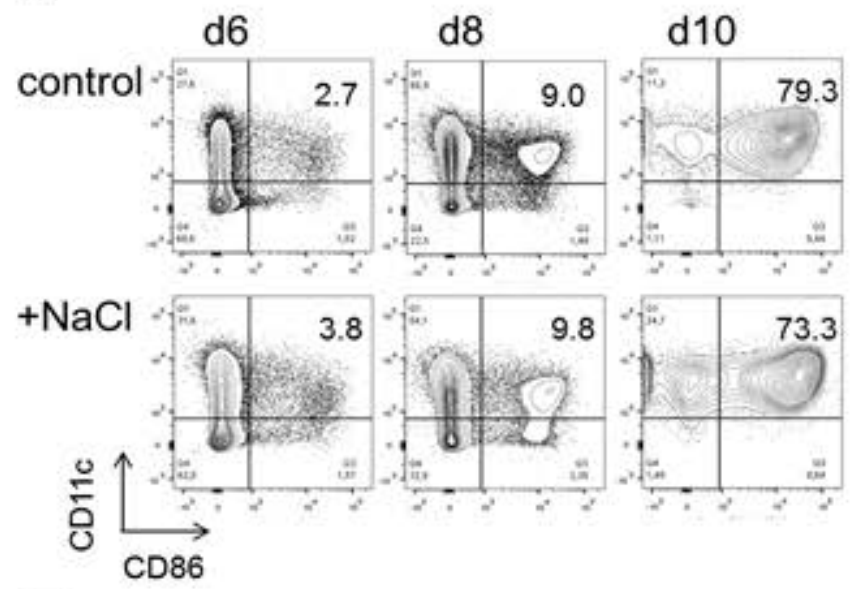

F

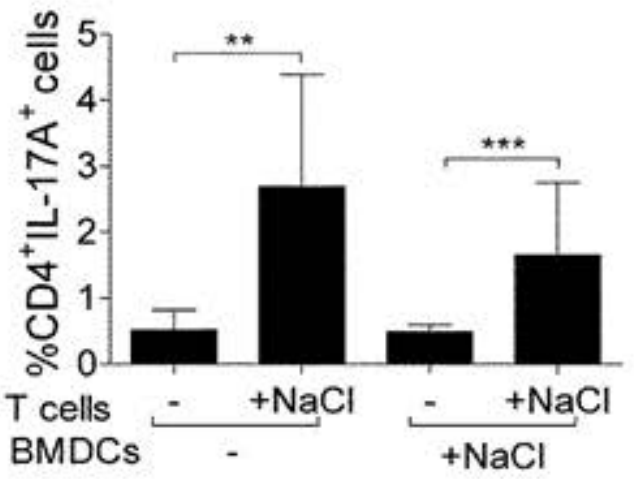

$\mathrm{H}$

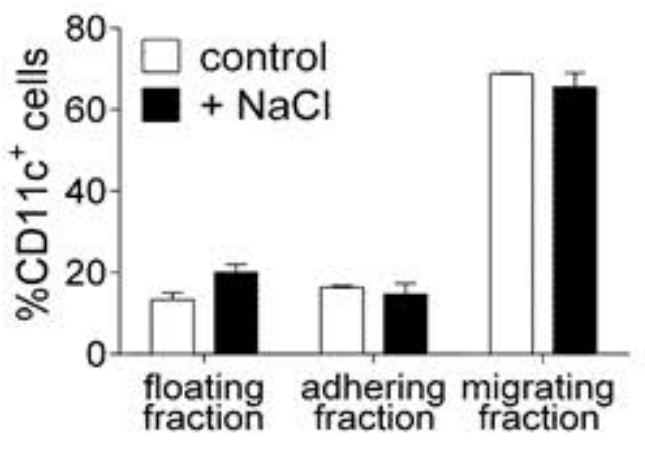

Jörg et al. Figure 2 
A

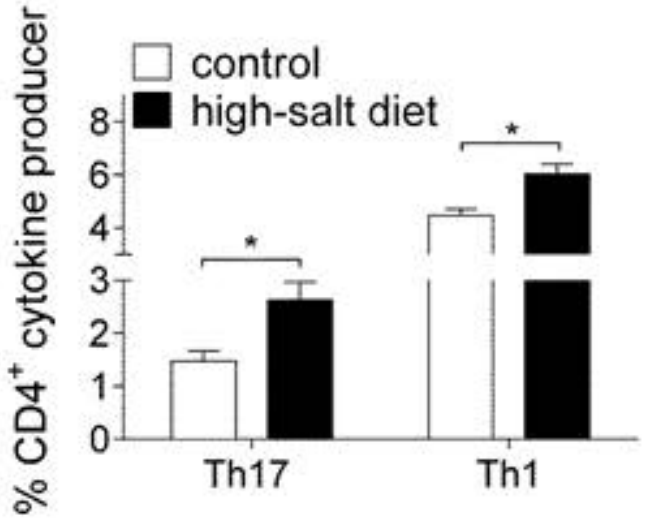

C

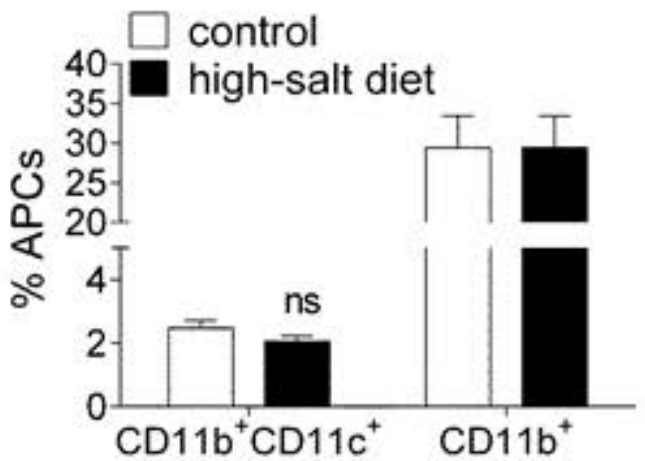

$E$

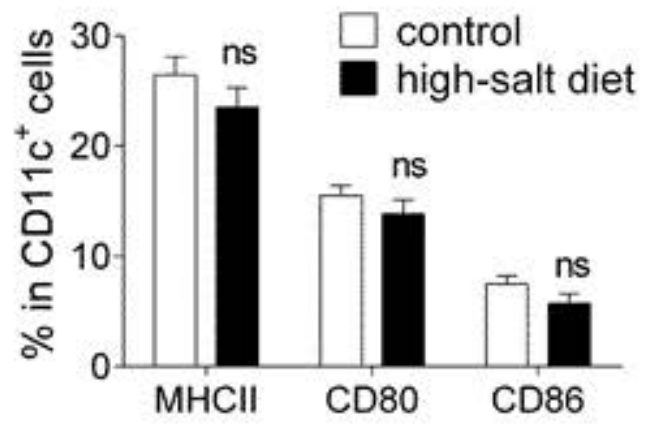

F

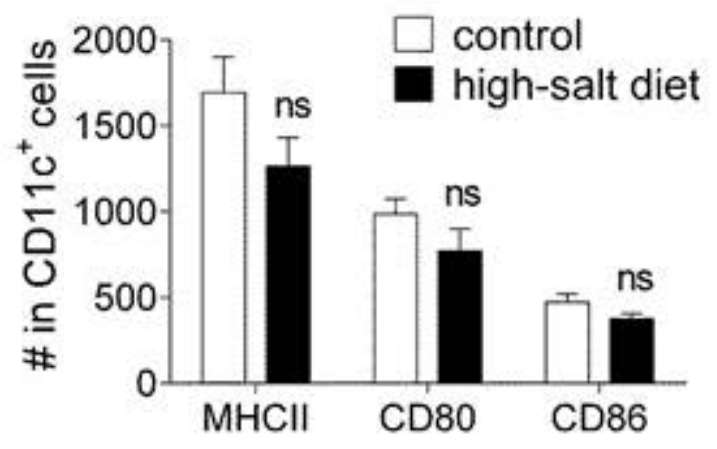

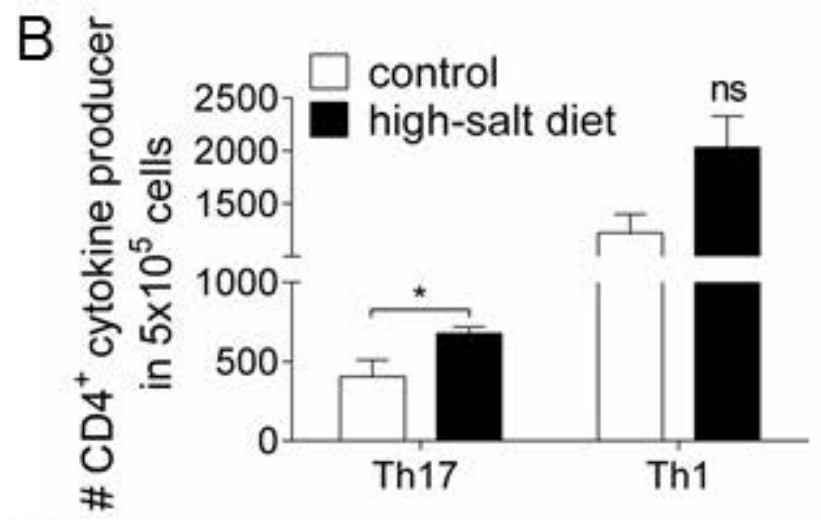

D

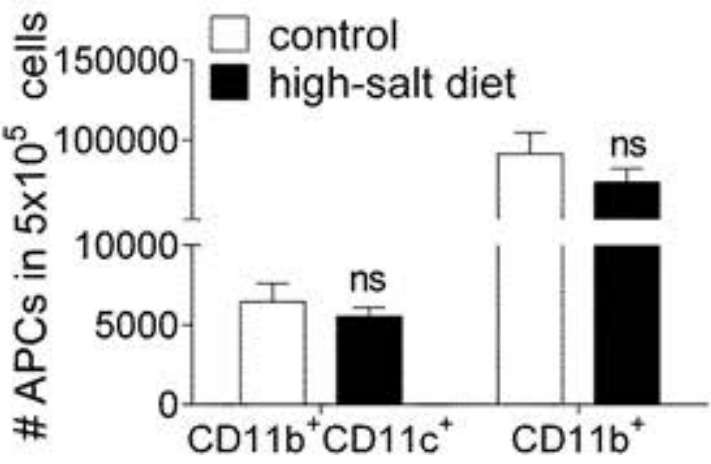

G

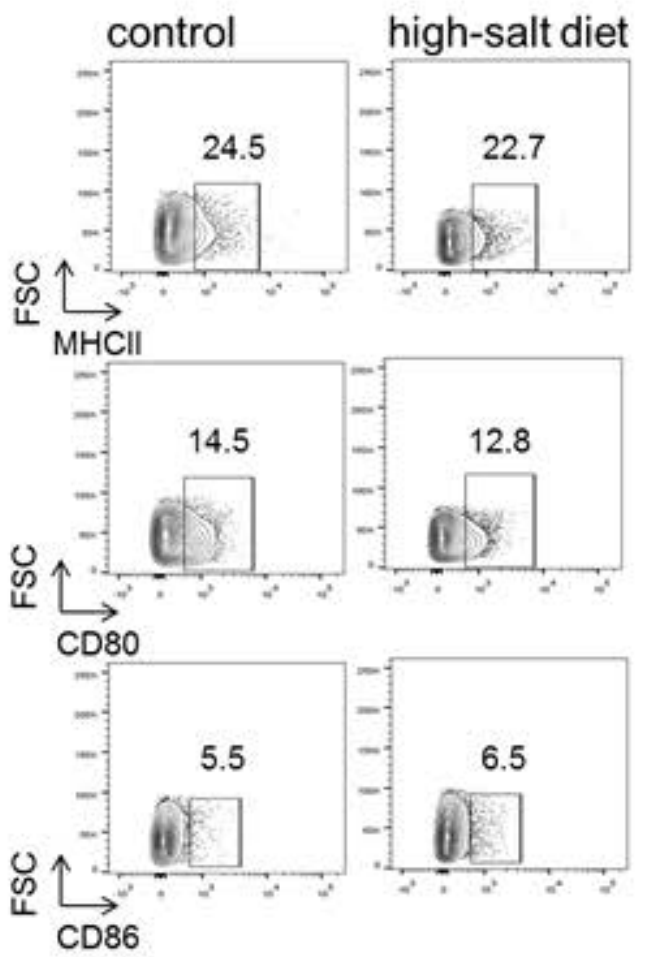

\section{Jörg et al. Figure 3}


A

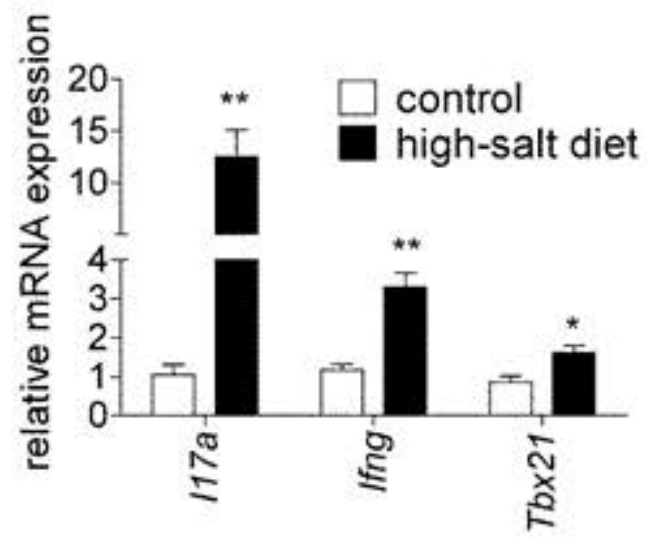

C

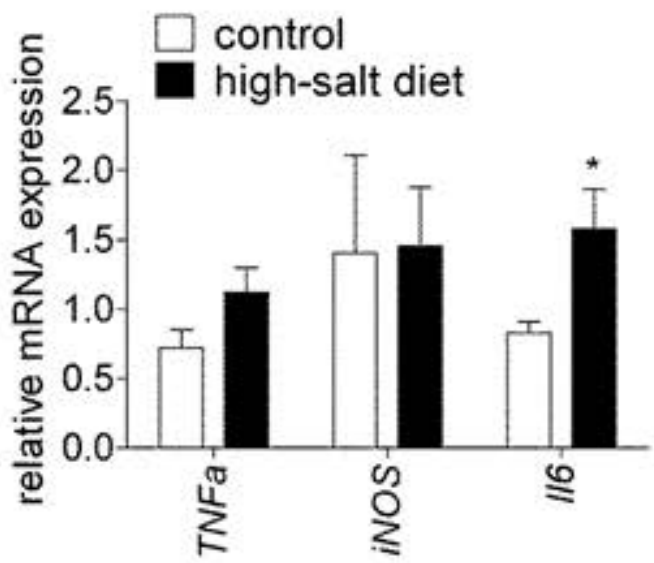

E

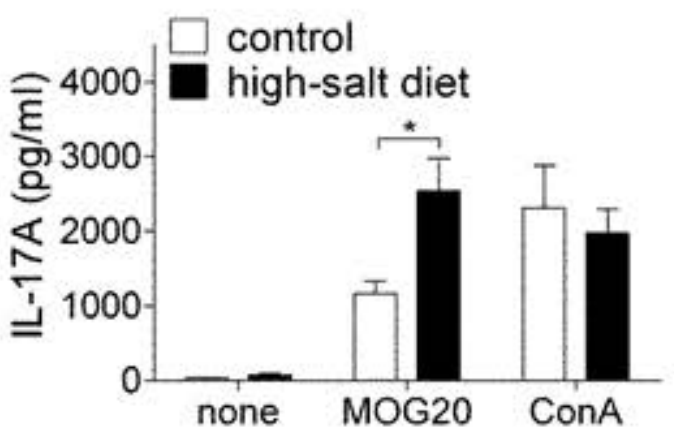

G

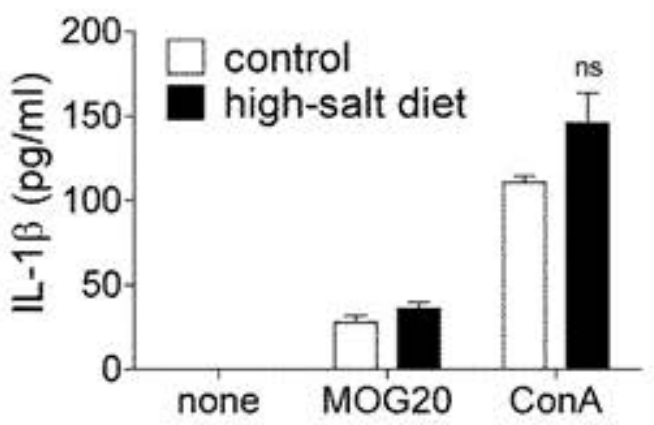

$B$ 은

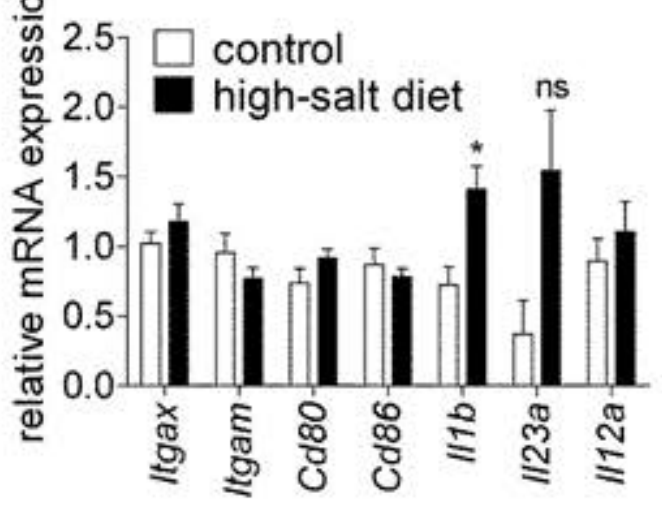

D

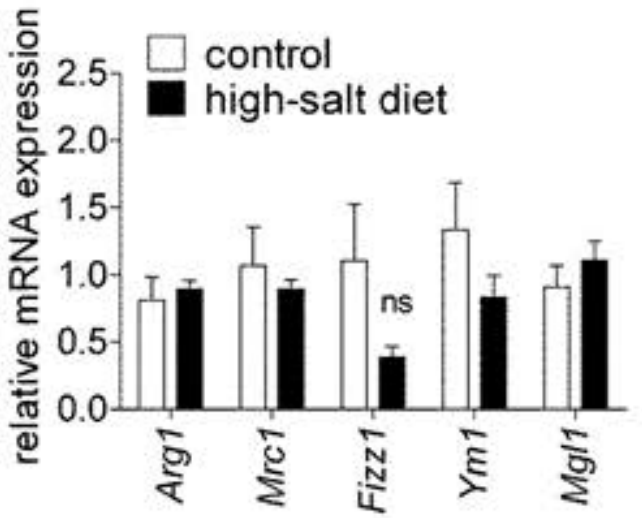

F

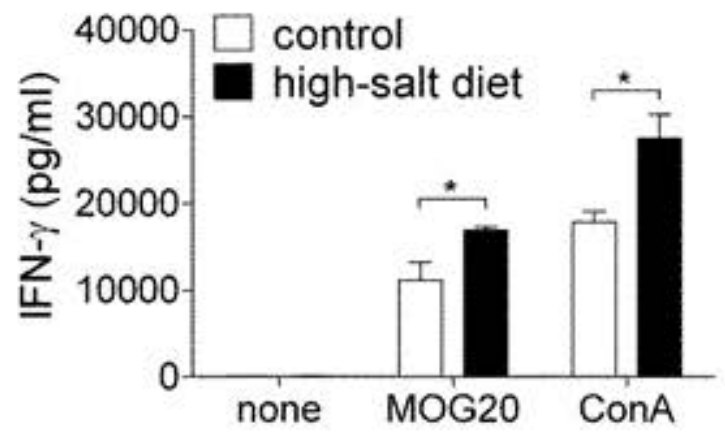

$H$

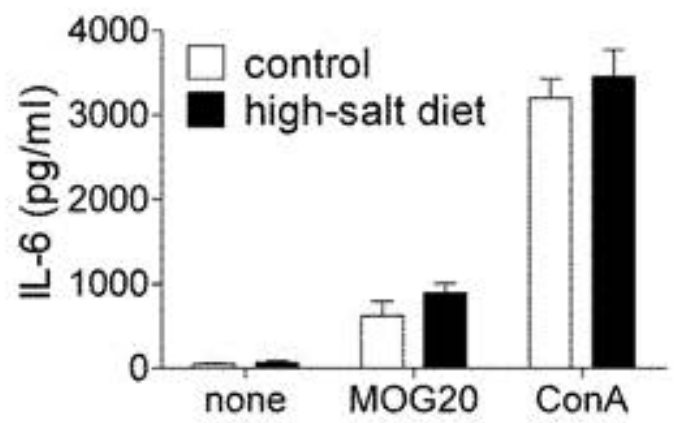

Jörg et al. Figure 4 

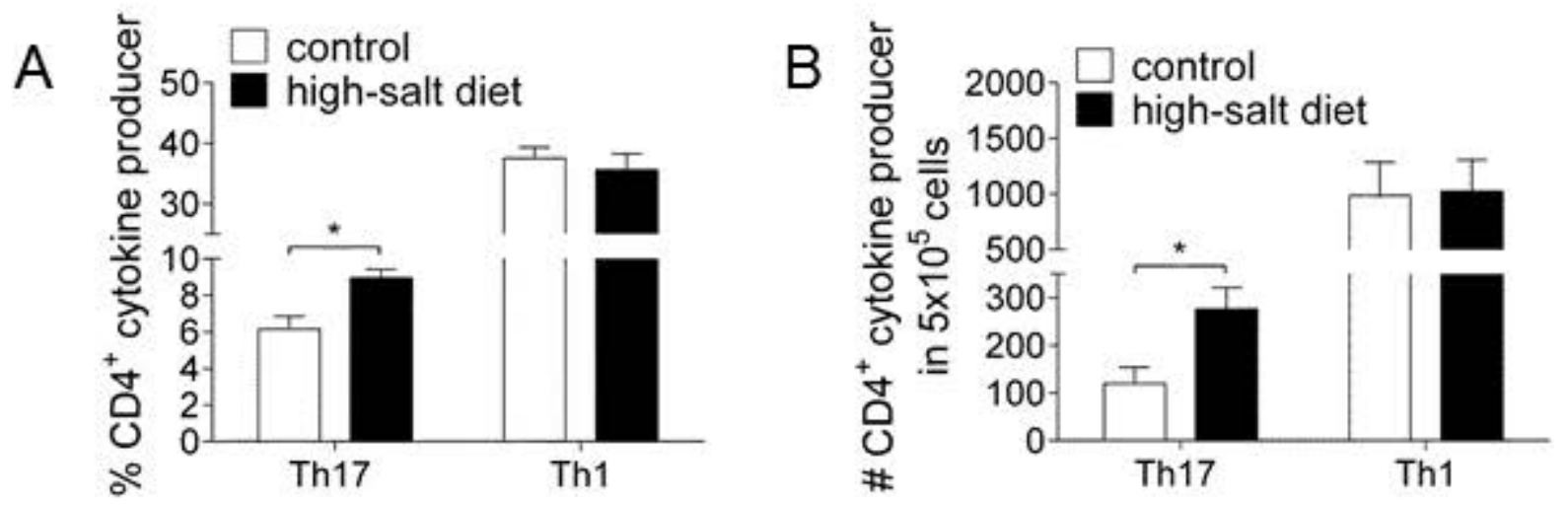

C

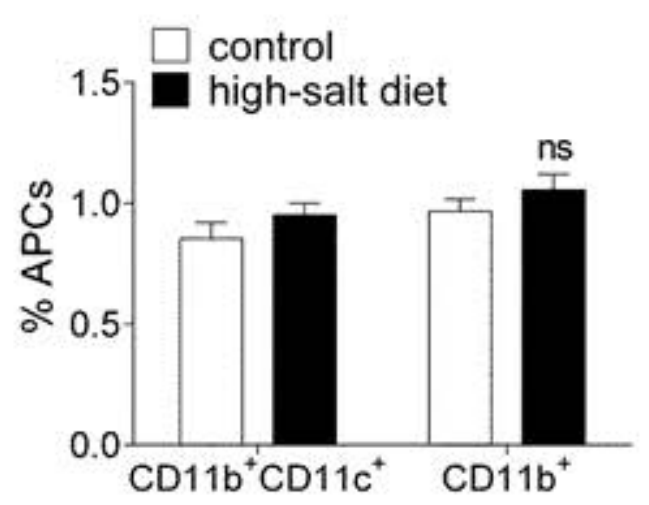

D

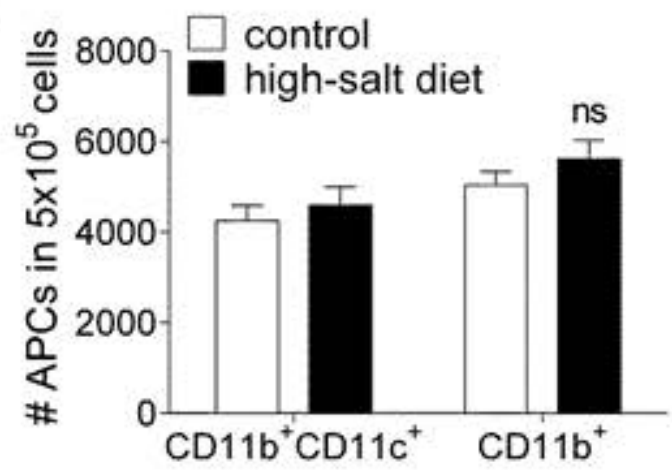

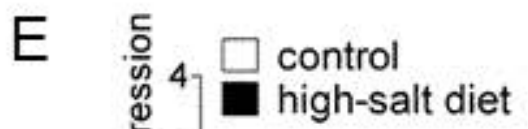
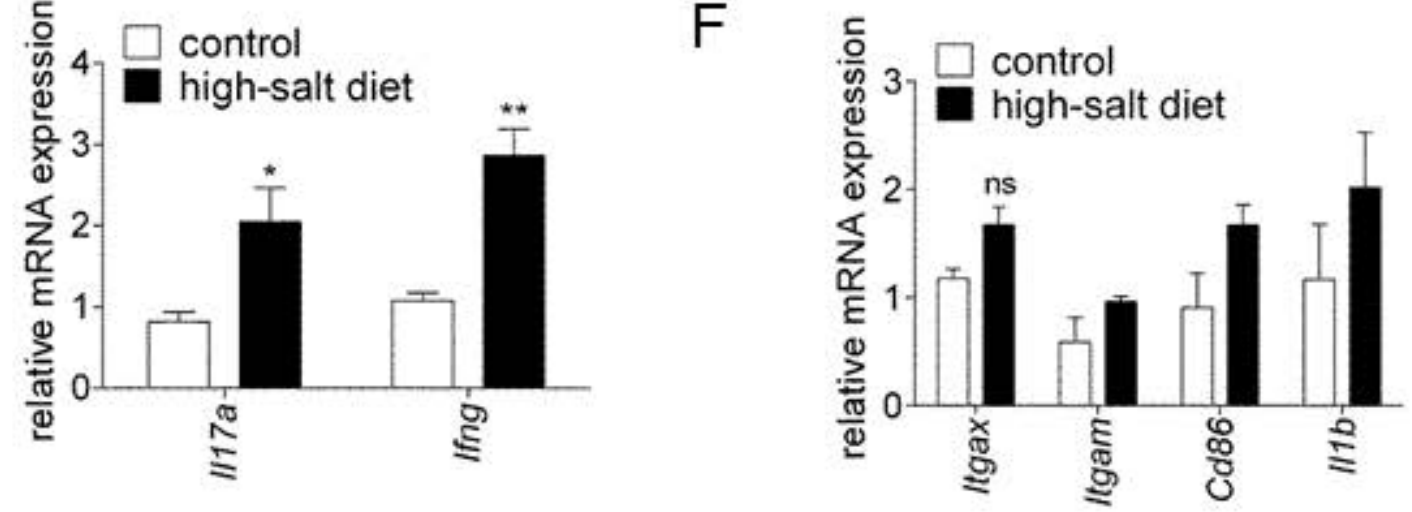

G

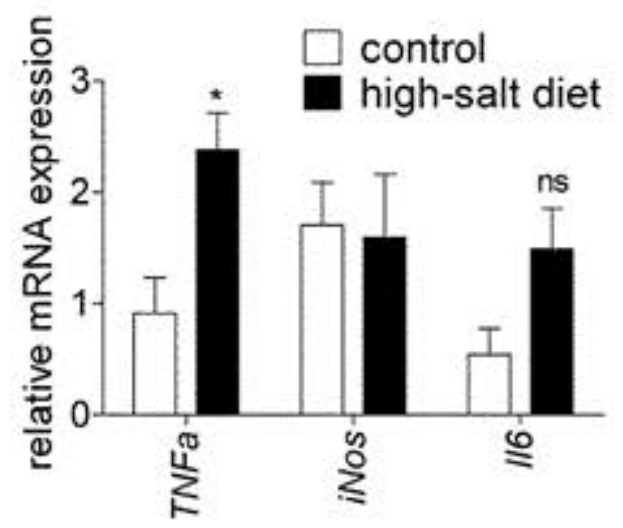

$\mathrm{H}$

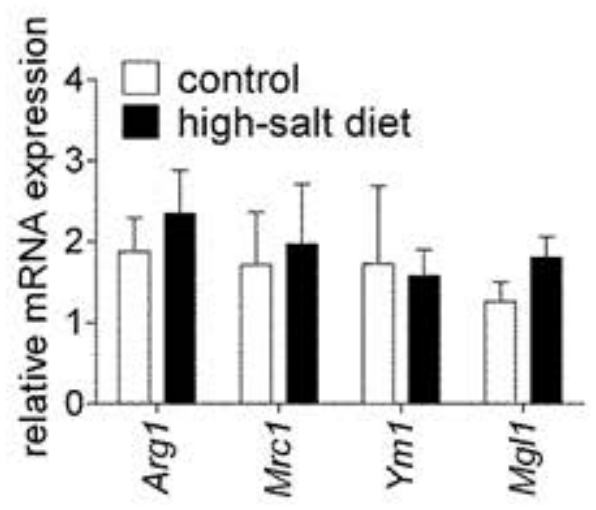

Jörg et al. Figure 5 


\section{Supplement}

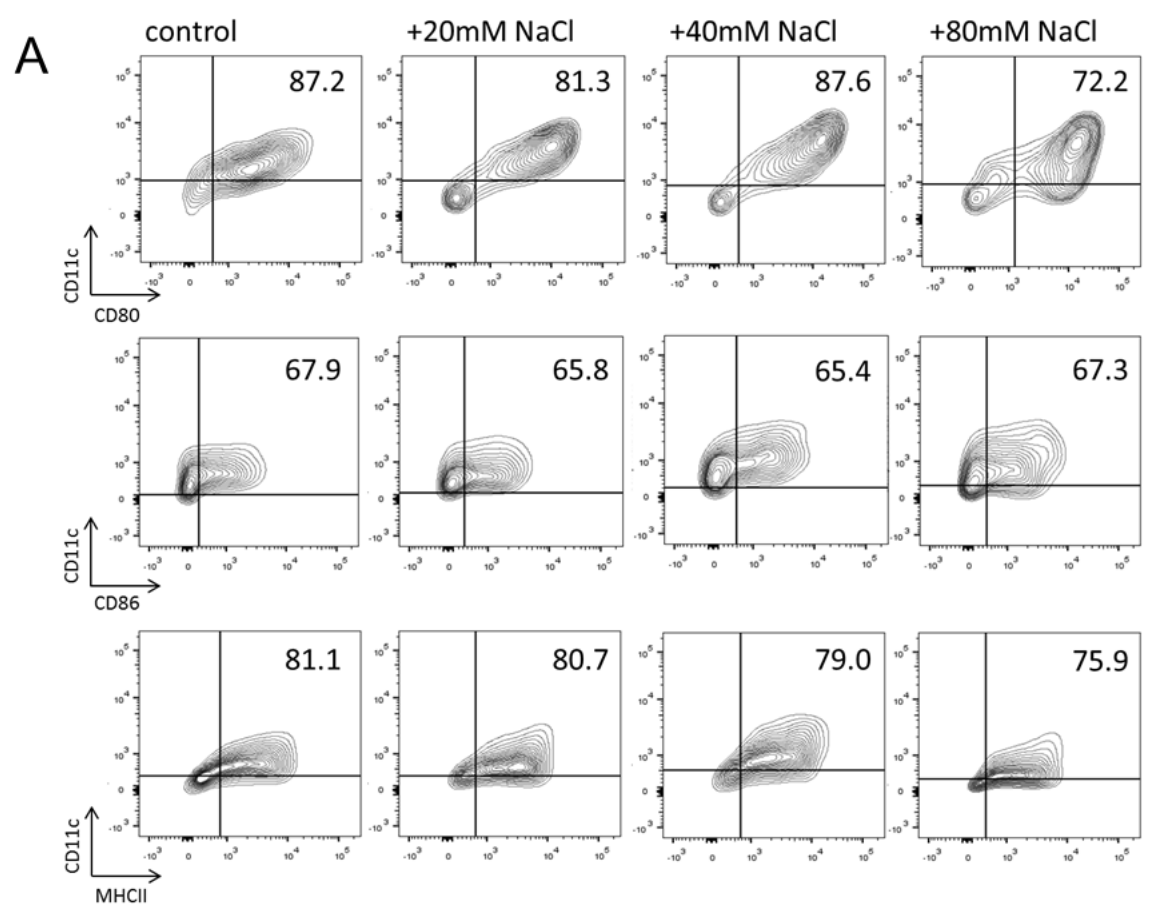

B

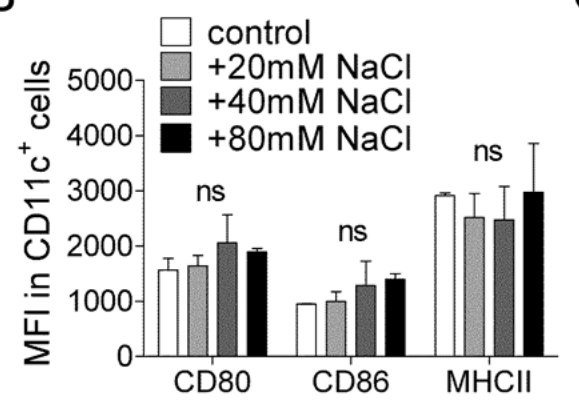

C

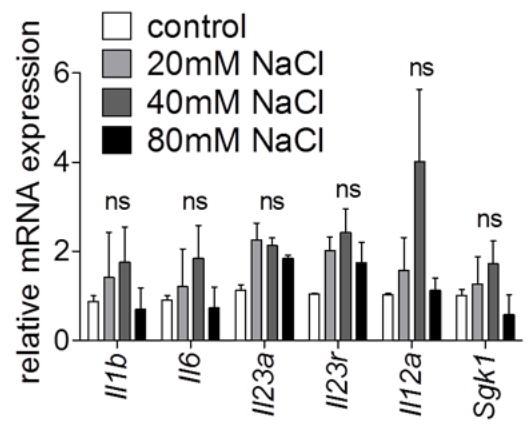

\section{Supplementary Figure 1}

$\mathrm{NaCl}$ does not affect DC generation in vitro.

BMDCs were cultured in the presence or absence (control) of an excess of 20, 40 or

$80 \mathrm{mM} \mathrm{NaCl}$. Cells were harvested on day 10 of culture and analyzed by flow

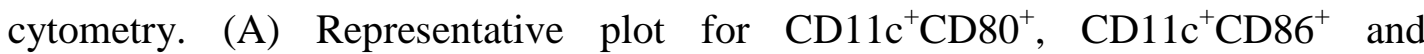

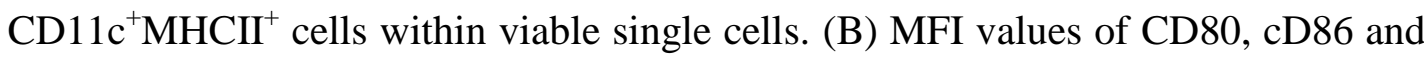

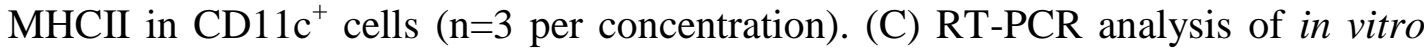
generated BMDCs $(\mathrm{n}=3$ per concentration). All data are shown as mean \pm SEM. $\mathrm{ns}=$ not significant. 


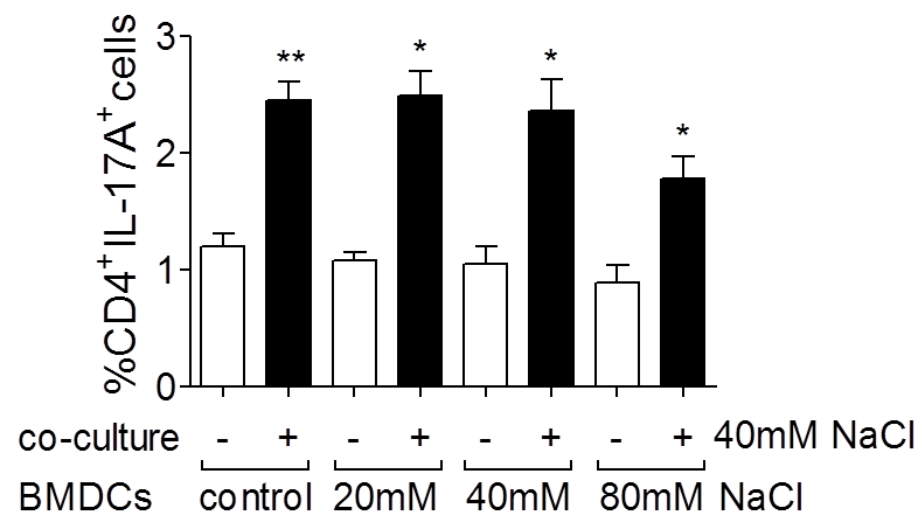

\section{Supplementary Figure 2}

$\mathrm{NaCl}$ does not impact on the $\mathrm{T}$ cell stimulatory capacity of in vitro generated BMDCs. Addition of $40 \mathrm{mM} \mathrm{NaCl}($ co-culture + ) to a co-culture assay of naïve $\mathrm{T}$ cells and BMDCs generated in the presence or absence (BMDCs control) of 20, 40 or $80 \mathrm{mM} \mathrm{NaCl}$ ( $\mathrm{n}=3$ per concentration). All data are shown as mean \pm SEM. $* \mathrm{p}<$ $.05, * * \mathrm{p}<.01$. 
A
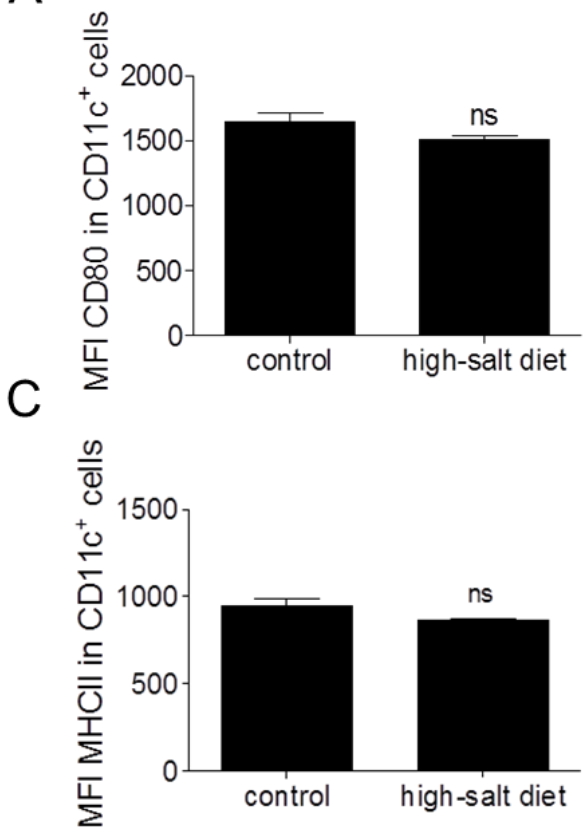

B

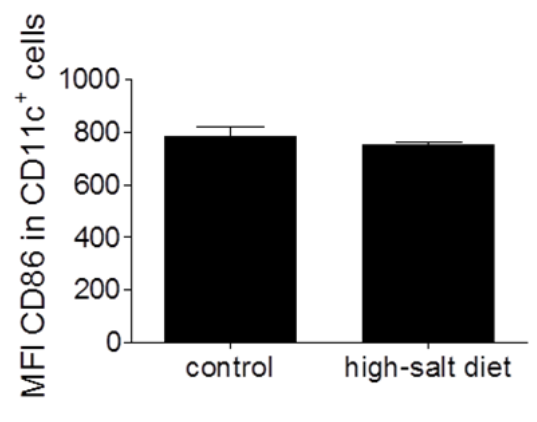

\section{Supplementary Figure 3}

High dietary salt directly acts on T cells rather than on APCs in the priming phase of EAE. Wild-type mice were adapted to a high-salt diet two weeks prior to active immunization with $\mathrm{MOG}_{35-55}$ peptide. (A-C) Ex vivo flow cytometry analysis of MFI values of (A) CD80 in CD11 $\mathrm{c}^{+}$cells (B) CD86 in CD11 $\mathrm{c}^{+}$cells and (C) MHCII in $\mathrm{CD} 11 \mathrm{c}^{+}$cells in the spleen on day 10 p.i. ( $\mathrm{n}=5$ mice per group). All data are shown as mean \pm SEM. $n s=$ not significant, MFI $=$ mean fluorescence intensity . 

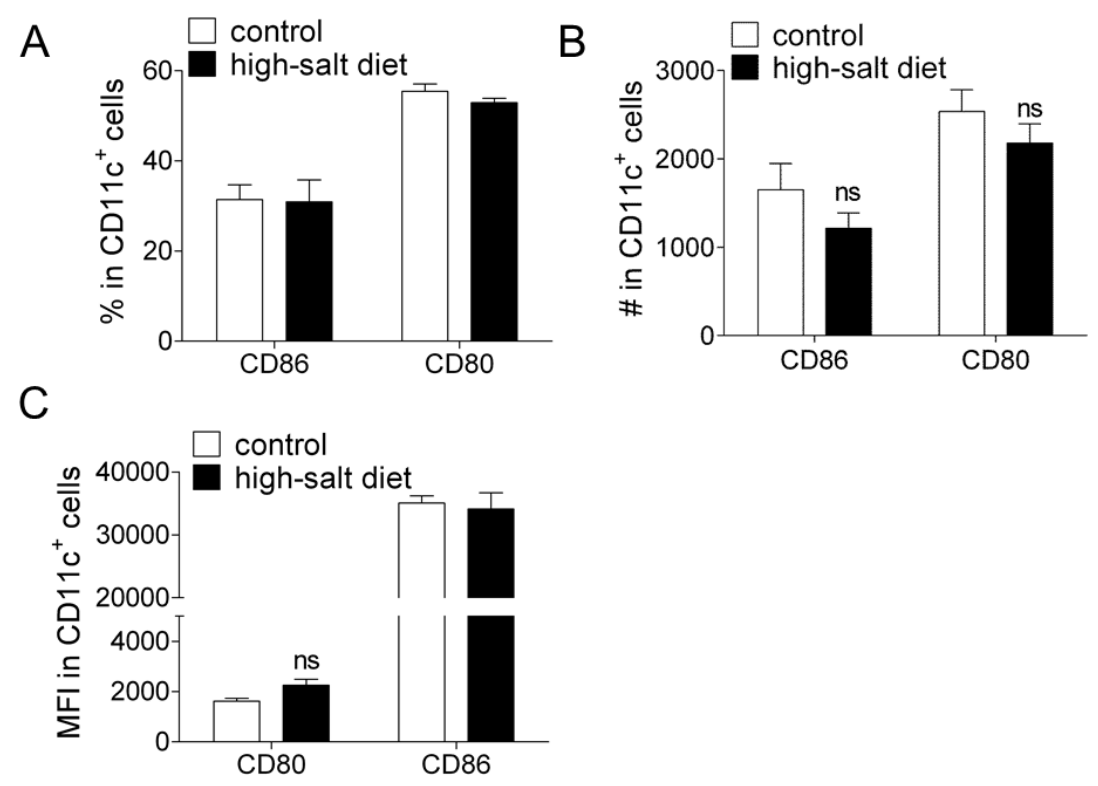

\section{Supplementary Figure 4}

High dietary salt does not increase infiltrating mDCs in the CNS.

Wild-type mice were adapted to a high-salt diet two weeks prior to active immunization with $\mathrm{MOG}_{35-55}$ peptide. (A-C) Ex vivo flow cytometry analysis of the spinal cord on day 14 p.i. ( $\mathrm{n}=5$ mice per group). (A) Frequencies and (B) total cell numbers of $\mathrm{CD} 11 \mathrm{c}^{+} \mathrm{CD} 80^{+}$and $\mathrm{CD} 11 \mathrm{c}^{+} \mathrm{CD} 86^{+}$cells invading the spinal cord. (C) MFI of CD80 and CD86 in CD11 ${ }^{+}$cells in the spinal cord on day 14p.i. All data are shown as mean \pm SEM. $n s=$ not significant, $\#=$ total cell number, MFI $=$ mean fluorescence intensity. 

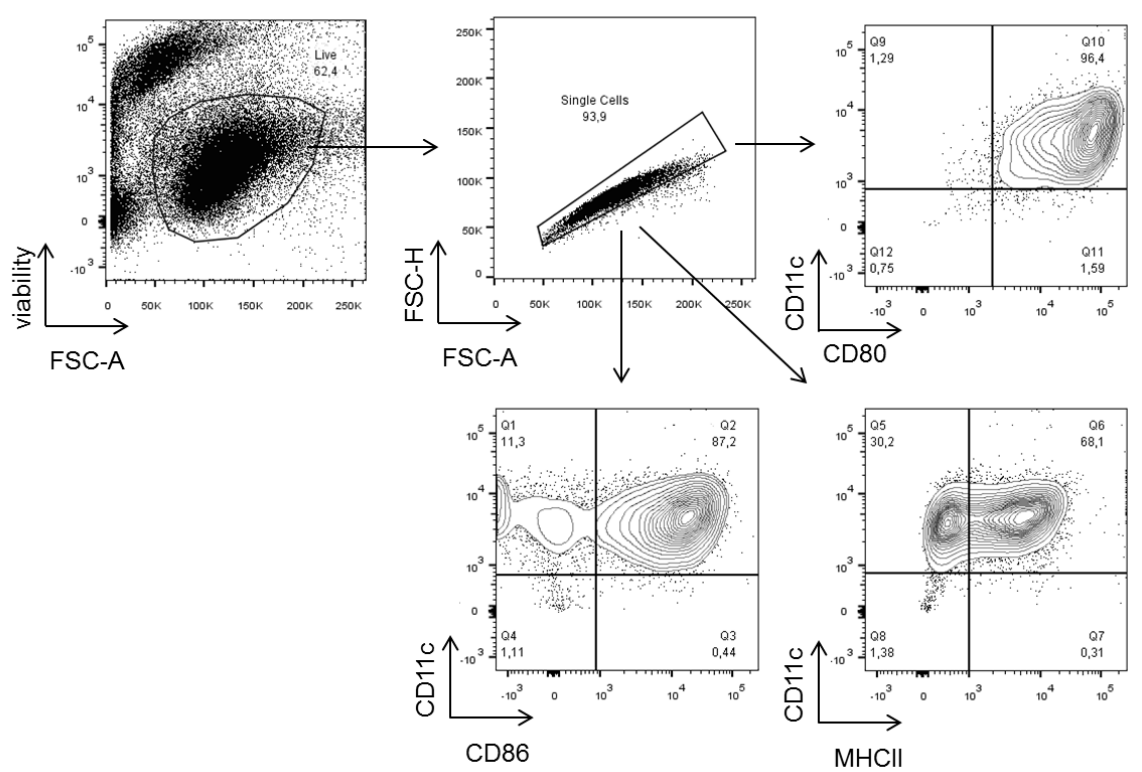

\section{Supplementary Figure 5}

Flow cytometry gating strategy for in vitro generated BMDCs.

In vitro generated BMDCs were stained for flow cytometry analysis on day 10 of culture and analyzed for $\mathrm{CD} 11 \mathrm{c}^{+} \mathrm{CD} 80^{+}, \mathrm{CD} 11 \mathrm{c}^{+} \mathrm{CD} 86^{+}$and $\mathrm{CD} 11 \mathrm{c}^{+} \mathrm{MHCII}^{+}$cells within viable single cells.
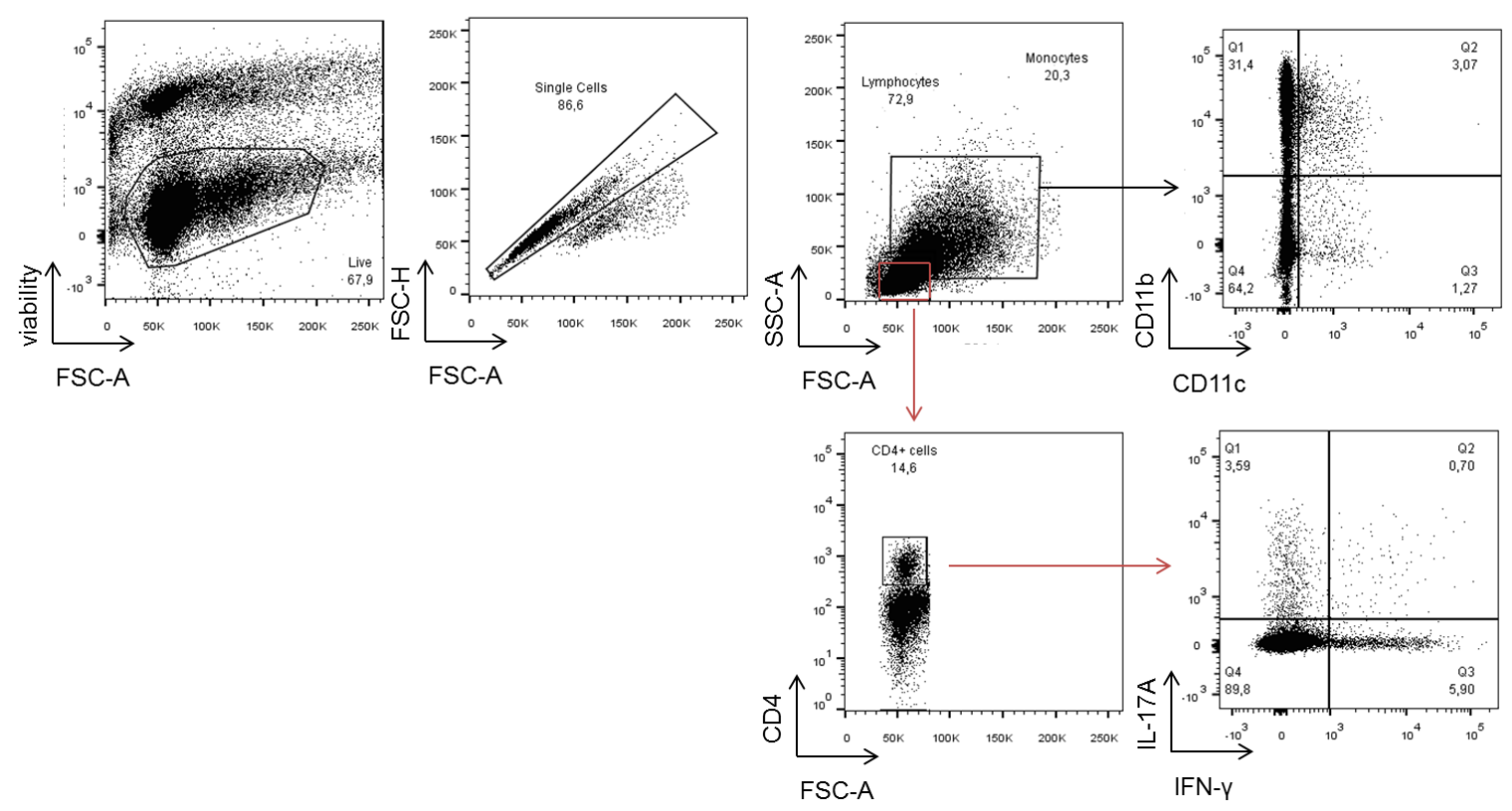


\section{Supplementary Figure 6}

Flow cytometry gating strategy for ex vivo obtained splenocytes.

Splenocytes were isolated on day 10 p.i. and stained for flow cytometry analysis. CD $11 \mathrm{c}^{+}$and $\mathrm{CD} 11 \mathrm{~b}^{+}$cell frequencies were quantified within viable monocytes. IL$17 \mathrm{~A}^{+}$and IFN- $\gamma^{+}$cells were quantified within viable $\mathrm{CD}^{+} \mathrm{T}$ cells after gating for single lymphocytes. 